\title{
EFFECT OF PROPOLIS ON THE IMMUNE RESPONSE AND MEAT QUALITY IN EXPERIMENTALLY ESCHERICHIA COLI INFECTED BROILERS
}

\author{
MONA, S.I. ${ }^{1}$; NAGLAA, A.A. ${ }^{2}$ AND HALA, M. ISMAIL ${ }^{3}$ \\ ${ }^{1}$ Poultry Diseases Department. Mansoura Lab. Animal Health Research Institute. ARC. Egypt. \\ ${ }^{2}$ Food Hygiene. Tanta Lab. Animal Health Research Institute. ARC. Egypt. \\ ${ }^{3}$ Pathology Department. Mansoura Lab. Animal Health Research Institute. ARC. Egypt.
}

Received: 1 April 2021; Accepted: 28 April 2021

\begin{abstract}
The present study was conducted to evaluate the effects of propolis on performance, immune response and meat quality of broiler chickens infected with E. coli. A total of 120 day old chicks were divided randomly into 4 equal experimental groups. The $1^{\text {st }}$ group $\left(\mathrm{G}_{1}\right)$ was fed a basal diet and infected with $E$. coli $\left(1 \times 10^{8} \mathrm{CFU}\right)$ at 5 days of age. The $2^{\text {nd }}$ group $\left(\mathrm{G}_{2}\right)$ was fed a basal diet supplemented with propolis $(400 \mathrm{mg} / \mathrm{kg}$ diet $)$ and infected with $E$. coli $\left(1 \times 10^{8} \mathrm{CFU}\right)$ at 5 days of age. The $3^{\text {rd }}$ group $\left(\mathrm{G}_{3}\right)$ was fed a basal diet supplemented with propolis $(400 \mathrm{mg} / \mathrm{kg}$ diet $)$. The $4^{\text {th }}$ group $\left(\mathrm{G}_{4}\right)$ was fed a basal diet and served as a control. Propolis supplemented groups showed a significantly increased body weight, decreased mortality, decreased reisolation frequency of $E$. coli from internal organs and early recovery of infection. Propolis improved significantly the phagocytic activity in both supplemented groups. Total leukocytic count was significantly increased in propolis supplemented group with significant increase in lymphocytes and concurrent decrease in heterophils. Propolis improved the Newcastle disease vaccine antibody production in both supplemented groups. Propolis treated groups have significantly higher breast muscles protein concentration and lower fat content. Also, it showed a significant reduction on the bacterial load in the examined samples in comparison to the samples of the non supplemented groups.
\end{abstract}

Keywords: Propolis - E. coli - immune response - meat quality

\section{INTRODUCTION}

Collibacillosis is a common wide spread disease of poultry. It causes a great economic losses to poultry industry through increasing mortalities, decreasing productivity and down grading meat quality and increased

Corresponding author: MONA, S.I.

E-mail address: dr_mona.saidibrahim@yahoo.com

Present address: Poultry Diseases Department. Mansoura Lab. Animal Health Research Institute. ARC. Egypt. condamination of carcasses, about 36$43 \%$, during processing due to lesions of E. coli as septicemia, fibrinous pericarditis, fibrinous perihepatitis, peritonitis and air saculitis (Hasan et al., 2011; Abd El-Tawab et al., 2015). E. coli infection negatively affect humoral and cellular immune response, it can alone induce marked lymphocytic depletion from thymus and bursa, so the clinical $E$. coli infection is indicative of immune suppression (Nakamura et al., 1990; Kumari et al., 2020). 
The antibiotics were used in poultry production as growth promotor and for treatment. The un controlled usage of antibiotics resulted in the appearance of multidrug resistant $E$. coli serotypes that were resistant to tetracycline, ciprofloxacine, co-trimoxazol and gentamycin (Hussain et al., 2017) making collibacillosis difficult to treat, in addition of increasing the risk of transmission of the resistance gene to other pathogens and pass to human via food causing a serious public health threat. The existence of shared antimicrobial resistance between $E$. coli isolates from broiler carcasses and human was demonstrated by Ramadan et al. (2020) so there is an increasing interest to replace antibiotics with natural products. In modern poultry production, work is now being done on poultry feed to further improve the quality and nutritional value of meat (Zdunczyk and Jankowski, 2013). The use of natural additives in poultry feed is particularly important, among which the use of propolis (Gregacevic et al., 2014).

Propolis is a natural resinous hive product that is collected by honey bees from plants, flowers and leaf buds and then modified by their enzymes (Babaei et al., 2016). Propolis contains several chemical bioactive compounds as polyphenols (flavonoid aglycones, phenolic aldehydes, phenolic acids, alcohols and their esters and ketones), steroids terpenoids, amino acids (Eyng et al., 2015), vitamins (A, C, D, E and $\mathrm{B} 1$, B2, B6, niacin and folate) and some micro and macro minerals like calcium, iron, copper, zinc, magnesium, manganese, nickel and cobalt (Zabaiou et al., 2017). It also contains some enzymes as glucose- 6- phosphatase, dehydrogenase, adenosine triphosphate and acid phosphatase (Yilmaz et al., 2003); (Kurek-Górecka et al., 2014).

The diversity of chemical composition of propolis are responsible for the antibacterial, antiviral, antifungal and immunomodulatory activity (klaric et al., 2018). It also gives propolis an additional advantage as antibacterial agent, the compination of different active ingredients with different concentrations prevents the bacterial resistance from occurring (Talas and Gulhan 2009); (Pamplona et al., 2011); (Eyng et al., 2013).

Several researchers have investigated the growth promoting effect of propolis by increasing feed intake, body weight gain and FCR (Shalmany and schivazad, 2006); (Hassan and Abdulla, 2011); (Klaric et al., 2018). Others have reported the potentiating effect of propolis on humoral and cellular immunity in broiler chicken (Attia et al., 2017); (Mohamed et al., 2019).

Propolis increased the aroma, taste, juiciness, softness properties of breast muscles of broiler, improved meat digestibility, tenderness and skin pigmentation (Haščík et al., 2011). Broiler chicks fed diet supplemented with propolis had significantly higher breast muscles protein, moisture concentration and bone strength (Rabie $e t$ al., 2018).

Propolis supplementation protects the hepatic tissue from hepatotoxic factors and increased the intestinal villi length (Tekeli et al., 2010); (Babinska et al., 2013).

In this study we assessed the efficacy of propolis as natural alternative to 
antibiotics to control collibacillosis. Propolis effect on growth performance, immune response, reisolation of E. coli, meat quality and pathological changes was investigated.

\section{MATERIALS AND METHODS}

\section{Chicks and ration:}

A total of 120 day-old chicks of mixed sex obtained from a breeder flock liberated from bacterial infection were used to study the effect of propolis on the immune response and meat quality in $E$. coli infected chicks. Birds were vaccinated against Newcastle disease (ND) using Hitchner B1at 7 days of age and Lasota vaccine at 18 and 28 days of age, and against Gumboro at 12 days of age. The chicks fed a starter ration from 1 to 21days of age (contained protein $21 \%$, fat $3.5 \%$ and energy $3054 \mathrm{Kcal} / \mathrm{kg}$ ) and grower ration from 21 to 35 days of age (contained protein $17.2 \%$, fat $2.5 \%$, energy $3020 \mathrm{Kcal} / \mathrm{kg}$ ). Both starter and grower ration were produced without any antibiotics and coccidiostats.

\section{Bacterial strain:}

E. coli (NCTC12241/ ATCC 25922) was obtained from Animal Health Research Institute, Dokki, Giza, Egypt.

\section{Propolis:}

Crud Egyptian propolis, from Dakahlia Governorate, was cut into small pieces and extracted using $70 \%$ ethanol (1:9) in dark warm place for 14 days. The alchoholic extract was evaborated under vaccum at $50^{\circ} \mathrm{C}$ until drying. The obtained dried extract was added to the ration at the concentration of $400 \mathrm{mg} / \mathrm{kg}$ of ration. (krell, 1996).

\section{Experimental design:}

A total of 120 unsexed one day old Cobb chicks were randomly divided into 4 equal experimental groups (30 chicks each). The $1^{\text {st }}$ group $\left(\mathrm{G}_{1}\right)$ was fed a basal diet and infected intratracheally with $E$. coli $1 \times 10^{8} \mathrm{CFU}$ at 5 days of age. The $2^{\text {nd }}$ group $\left(\mathrm{G}_{2}\right)$ was fed a basal diet supplemented with propolis $(400 \mathrm{mg} / \mathrm{kg}$ diet) and infected intratracheally with $E$. coli $1 \times 10^{8} \mathrm{CFU}$ at 5 days of age. The $3^{\text {rd }}$ group $\left(\mathrm{G}_{3}\right)$ was fed a basal diet supplemented with propolis $(400 \mathrm{mg} / \mathrm{kg}$ diet). The $4^{\text {th }}$ group $\left(\mathrm{G}_{4}\right)$ was fed basal diet without any additives and served as a control. The birds were challenged intratracheally with $0.2 \mathrm{ml}$ of a stock solution of E. coli containing $1 \times 10^{9}$ $\mathrm{CFU} / \mathrm{ml}$, providing a dose of $1 \times 10^{8} \mathrm{CFU}$.

\section{Measured parameters}

5. 1. Mortality, clinical signs, and postmortem examination:

The experimental birds were noticed periodically for clinical signs. Dead birds were subjected to post mortem examination, three birds from each group were slaughtered and sacrificed weekly for recording the suspected lesion.

\subsection{Performance:}

Oncoming, the chicks were weighed, performance parameters that includes the body weight $(\mathrm{BW})$, weight gain (WG) feed intake (FI) and Feed conversion ratio (FCR) were recorded.

\subsection{Bacterial reisolation:}

Reisolation of $E$. coli from lung, liver and heart of weekly slaughtered birds on Eosin methylene blue agar media.

\subsection{Evaluation of immune response:}

Blood samples weekly collected from slaughtered birds were used for detecting the phagocytic activity, differential leukocytic count and Haemagglutination inhibition test for detection of antibodies against Newcastle disease vaccine. 


\subsubsection{Phagocytic activity}

Blood samples were collected in vials containing heparin. Measurment of phagocytic activity of peripheral blood monocytes using Candida albicans was adapted as described by Anthony et al. (1985), Boyum (1986), Goddeeris et al. (1986), Chu and Dietert (1989) and Wilkinson (1976).

Phagocytic activity $\%=$ macrophages containing yeast/ total number of macrophages X 100

Phagocytic index =number of yeast phagocytized / number of phagocytic cells containing yeast

\subsubsection{Differential leukocytic count:}

Blood samples were collected in vials containing EDTA. Blood film was prepared according to Lucky (1977) for differential leukocytic count, the percentage of each type of cells were calculated according to Schalm (1986).

\subsubsection{Haemagglutination inhibition test for detection of Newcastle disease vaccine antibodies:}

Serum was separated from blood samples by centrifugation at $3000 \mathrm{rpm}$. Microtechniqe of haemagglutination inhibition test was done according to Takatsy (1955). Antibody titer was calculated according to Brugh (1978).

\subsection{Evaluation of meat quality:}

At the end of the experiment (35 days), 24 birds (6 birds per group) were chosen at random. Birds were slaughtered, at the slaughterhouse. After evisceration, the carcasses were kept at approximately 18 ${ }^{\circ} \mathrm{C}$ for $1 \mathrm{~h}$ post mortem. Breast meat samples (pectoralis major) were dissected from each left half-carcass (right half-carcasses were assigned to other analysis) and stored at $4{ }^{\circ} \mathrm{C}$ until 24 $\mathrm{h}$ post mortem. The samples (boneless breast without skin) were individually packaged in labelled bags and stored at $18{ }^{\circ} \mathrm{C}$ for prior to analysis.

\subsubsection{Chemical composition:}

Samples of chicken breast muscle without skin $(n=24)$ were analyzed for

a) Crude protein content was estimated by means of the Kjeldahl method using BÜCHI B324 apparatus (Switzerland) (AOAC, 1990).

b) Ash using the ash content procedure described by the AOAC (1990).

c) The fat was determined by extraction with petroleum ether using a Tecator Extraction System 1045 Soxtec (Foss Tecator AB, Hoganas, Sweden) (AOAC, 1990).

d) Determination of moisture (Corzo et al., 2009).

e) Determination $\mathrm{pH}$ according to Biswas et al. (2007).

\subsubsection{Microbiological evaluation:}

a) Total Plate Count (USDA, 2011). By using Nutrient agar media.

b) Total Enterobacteriaceae count (ISO, 2001). By using Violet Red Bile Glucose Agar (VRBG) media.

c) Total Coliform count (FDA, 2012). By using Violet Red Bile gar (VRB).

d) Total Staphylococci count (USDA, 2011). By using Baird Parker agar media.

e) Total Psycrotrophic count (USDA, 2011). By using standard plate count agar media. 


\subsubsection{3: sensory evaluation:}

Sensory profiles were determined by panelists were instructed on the assessment criteria. Panelists were asked to evaluate the samples of breast muscle for aroma ( 1 = very poor, $5=$ very good $)$, juiciness $(1=$ extremely dry, $5=$ extremely juicy), tenderness $(1=$ extremely tough, 5 = extremely tender), and overall acceptability $(1=$ not acceptable, 5 = extremely acceptable) on a 5-point hedonic scale. The samples were presented to the panelists monadically on plain white porcelain plates. Panelists were provided with water for neutralization of receptors before and between the samples. The panel evaluated each sample in triplicate over an 8-week period $(n=6)$ (Pelin-Can and Arslan, 2011).

\subsection{Pathological studies:}

\subsubsection{Histopathological examination:}

Tissue specimens from bursa, thymus, spleen, lung, liver, intestine and heart of all experimental groups were collected at 21 of age and fixed in $10 \%$ neutral buffered formalin. The tissues were prepared for routine histopathological examination (Bancroft et al., 2013) and examined using the light microscope (Olympus CX31, Japan) and photographed using a digital camera (Olympus, Camedia C-5060, Japan).

\subsubsection{Immunohistochemistry investigations:}

For detection the possitive immune cells in spleen, bursa and thymus: Paraffin sections from the spleen, bursa of fabricius and thymus were used for immunohistochemical detection of CD79 (B-lymphocytes) in spleen and bursa of fabricius and CD3 (T- lymphocytes) in thymus at day 21 of age. The tissue sections ( $3 \mu \mathrm{m} \quad$ thick), were deparaffinized and hydrated then washed by distal water. Antigen retrieval was applied in a water bath using citrate buffer (pH6) for 20 minutes. The endogenous peroxidase activities were removed with $3 \%$ hydrogen peroxide ( $\mathrm{H} 2 \mathrm{O} 2)$, then sections were incubated in diluted polyclonal primary antibody for one hour at room temperature in a humidified chamber for CD79 (obtained from Novus Biologicus company) and CD3 polyclonal rabbit anti-human CD3 (Dako) at 1 in 300 dilutions. The primary antibodies were detected in all experimental groups. The staining was performed using Power-StainTM 1.0 Poly HRP DAB according to the manufacturer's instructions. The sections were rinsed three times for $5 \mathrm{~min}$ each with Phosphate buffered saline, and were incubated in Poly HRP Conjugate for 15 minutes at room temperature. A mixture of $\mathrm{DAB}$ chromogen visualized the sections, then counterstained with hematoxylin and dehydrated and mounted (Anis et al., 2013).

\subsubsection{Scoring of the positive immune cells in bursa, spleen and thymus:}

The relative frequency of B-lymphocytes and $\mathrm{T}$ lymphocytes per focus was calculated according to the point count method, by using digital an Axiostar plus microscope interfaced with an Axiostar plus digital camera and Axiovision 4.1 software (Carl Zeiss) at a magnification of 100 (Weibel, 1969).

\section{Statistical analysis:}

The data was set as mean \pm standard error and was analyzed using analysis of variance (ANOVA). The significance of difference between means at $\mathrm{P}<0.05$ was calculated using Duncan test. (Steel and Torrie, 1980). 


\section{RESULTS}

The experimental study was done to evaluate propolis as a feed additive to decrease the adverse effect of collibacillosis in broilers instead of using antibiotics.

\section{Clinical signs, mortality and postmortem lesions:}

The clinical signs of $E$. coli infected group (G1) appeared $24 \mathrm{~h}$ after infection. Birds showed depression, inappetence, ruffled feathers, droppy wings, huddling together and greenish diarrhea. The signs continued for 2 weeks post infection. These signs were less sever in E. colipropolis supplemented group (G2) and lasted for only one week post infection. Morbidity was decreased from $53.3 \%$ in (G1) to $16.6 \%$ in (G2). Group 3 and group 4 showed no signs of illness. Mortality was decreased from $26.6 \%$ in (G1) to 6.6\% in (G2). (Table 1).

Postmortem examination of dead birds revealed sever congestion of lung, liver, spleen, pericarditis, perihepatitis, unabsorbed yolk sac and enteritis.

E. coli infected birds (G1) showed sever congestion of all internal organs (lung, liver spleen, heart, and kidney) at $1^{\text {st }}$ week of age. At $2^{\text {nd }}$ week there was fibrinous pericarditis, fibrinous perihepatitis, airsaculitis and enteritis. At $3^{\text {rd }}$ week of age the there was a thick fibrin sheet on the liver surface causing adhesion with other internal organs. At $4^{\text {th }}$ and $5^{\text {th }}$ week there was only fibrinous pericarditis and perihepatitis.

In E. coli-propolis supplemented birds (G2) there was congestion of lung, liver and spleen at the $1^{\text {st }}$ week of age. At $2^{\text {nd }}$ week of age there was mild pericarditis, perihepatitis and airsaculitis. At $3^{\text {rd }}$ week and onward all dissected birds appeared normal.

\section{Performance:}

Propolis supplemented group (G3) showed a significant increase in mean body weight all over the experimental period when compared to other groups. From the $3^{\text {rd }}$ week of age until the end of the experiment G2 showed a significant increase in body weight when compared to G1 and control group (G4). Propolis increased the feed intake in both treated groups (G2 and G3) when compared to corresponding control groups (G1and G4). There is no difference in the FCR in propolis supplemented group (G3) when compared to control group (G4), but there is a decrease in FCR in E. colipropolis supplemented group (G2) in comparison to $E$. coli infected (G1). (Table 2).

\section{Reisolation:}

Propolis decreased the reisolation frequency of $E$. coli from lung, liver and heart in $E$. coli-propolis supplemented group (10/45) when compared to $E$. coli infected group (23/45). The highest frequency of reisolation was from lung followed by liver and heart. E. coliPropolis supplemented group showed early clearance of infection as early as $3^{\text {rd }}$ week of age while E. coli was still reisolated from lung until the end of experiment in $E$. coli infected group (G2). (Table 3).

\section{Evaluation of immune response: Phagocytic activity:}

E. coli infected group showed a significant decrease in phagocytic activity when compared to control group. Propolis increased significantly the phagocytic activity in both supplemented groups (G2 and G3) when compared to corresponding groups (G1 and G4). The 
phagocytic activity of the $E$. coli-propolis supplemented group was improved to reach the levels of control at the $4^{\text {th }}$ and $5^{\text {th }}$ week of age. (Table 4)

\section{Differential leukocytic count:}

Total leukocytic count was significantly increased in E. coli infected group (G1) with significant lymphocytopenia and heterophilia all over the experimental period when compared to control group (G4). Propolis supplemented group (G3) showed a significant increase in total leukocytic count all over the experimental period, significant increase in lymphocytes at the $1^{\text {st }}, 2^{\text {nd }}$ and $3^{\text {rd }}$ week of age and a significant decrease in heterophils at the $1^{\text {st }}, 2^{\text {nd }}, 3^{\text {rd }}$ and $4^{\text {th }}$ week of age when compared to control group (G4).

E. coli-propolis supplemented group (G2) revealed a significant decrease in total leukocytic count when compared to E. coli infected group (G1) while was significantly higher when compared to control (G4) all over the experimental period. There was a non-significant difference in lymphocytes and heterophils between $E$. coli-propolis supplemented group $(\mathrm{G} 2)$ and $E$. coli infected group $(\mathrm{G} 1)$ at the $1^{\text {st }}$ week of age, while there was a significant increase in lymphocytes and significant decrease in heterophil in E. coli-propolis supplemented group (G2) when compared to $E$. coli infected group (G1) from the $2^{\text {nd }}$ week of age and onward. Lymphocytes and heterophils showed a significant difference in $E$. coli-propolis supplemented group $(\mathrm{G} 2)$ during the $1^{\text {st }}$ and $2^{\text {nd }}$ week of age while there was a non significant difference during the $3^{\text {rd }}$, $4^{\text {th }}$ and $5^{\text {th }}$ week of age when compared to control group. There was a non significant difference in eosinophil, monocytes and basophils between the experimental groups. Table (5).

\section{Haemagglutination inhibition test for detection of Newcastle antibodies:}

Mean antibody titer against Newcastle disease vaccine was higher in propolis supplemented group (G3) when compared to control group (G4) all over the experimental period but a significant increase was seen only at $2^{\text {nd }}$ and $3^{\text {rd }}$ weeks of age. The E. coli-propolis supplemented group (G2) showed a higher antibody titer all over the experiment but a significant increase was seen during the $3^{\text {rd }}$ week of age when compared to E. coli infected group (G1). (Fig 1).

Table 1: Effect of propolis on morbidity and mortality rate.

\begin{tabular}{cccccc}
\hline & G1(E. coli) & G2(E. coli +Propolis) & G3(Propolis) & G4(control) \\
\hline \multirow{2}{*}{ Morbidity } & No & $18 / 30$ & $5 / 30$ & $0 / 30$ & $0 / 30$ \\
\cline { 2 - 6 } & $\%$ & $53.3 \%$ & $16.6 \%$ & $0 \%$ & $0 \%$ \\
\hline \multirow{2}{*}{ Mortality } & No & $8 / 30$ & $2 / 30$ & $0 / 30$ & $0 / 30$ \\
\cline { 2 - 6 } & $\%$ & $26.6 \%$ & $6.6 \%$ & $0 \%$ & $0 \%$ \\
\hline
\end{tabular}


Table 2: Effect of propolis on performance.

Age Group G1(E.coli) G2(E. coli +Propolis) G3(Propolis) G4(control)

\begin{tabular}{cccccc}
\hline $1 \mathrm{w}$ & BW & $227.2 \pm 5.96^{\mathrm{c}}$ & $241.5 \pm 5.78^{\mathrm{c}}$ & $284 \pm 2.99^{\mathrm{a}}$ & $259 \pm 5.84^{\mathrm{b}}$ \\
\hline $2 \mathrm{w}$ & BW & $546 \pm 19.53^{\mathrm{c}}$ & $583.5 \pm 11.92^{\mathrm{bc}}$ & $671.3 \pm 2.76^{\mathrm{a}}$ & $610 \pm 13.30^{\mathrm{b}}$ \\
\hline $3 \mathrm{w}$ & BW & $1032.5 \pm 34.13^{\mathrm{d}}$ & $1198.5 \pm 10.74^{\mathrm{b}}$ & $1332.5 \pm 8.91^{\mathrm{a}}$ & $1127 \pm 10.79^{\mathrm{c}}$ \\
\hline $4 \mathrm{w}$ & BW & $1523.8 \pm 49.34^{\mathrm{d}}$ & $1785 \pm 48.14^{\mathrm{b}}$ & $1960 \pm 12.46^{\mathrm{a}}$ & $1670 \pm 16.90^{\mathrm{c}}$ \\
\hline $5 \mathrm{w}$ & BW & $2158.3 \pm 64.95^{\mathrm{d}}$ & $2536.5 \pm 76.77^{\mathrm{b}}$ & $2858.3 \pm 17.02^{\mathrm{a}}$ & $2390 \pm 12.25^{\mathrm{c}}$ \\
\hline Total & WG & 2095.7 & 2473.5 & 2795.3 & 2328 \\
\hline & FI & 3162.8 & 3684 & 4071 & 3388.3 \\
\hline & FCR & 1.51 & 1.48 & 1.46 & 1.46 \\
\hline
\end{tabular}

Data was set as mean \pm Standard error. Means within the same row with different superscripts are significantly different $(\mathrm{P}<0.05)$.

BW: Body weight.

FI: feed intake.
WG: weight gain.

FCR: Feed conversion ratio.

Table 3: Effect of propolis on reisolation frequency of E. coli from lung, liver and heart.

\begin{tabular}{|c|c|c|c|c|c|}
\hline Age & organ & $\mathrm{G} 1($ E. coli $)$ & G2(E.coli+Propolis) & G3(Propolis) & G4(control) \\
\hline \multirow{4}{*}{$1^{\text {st }} \mathrm{W}$} & Lung & $3 / 3$ & $2 / 3$ & $0 / 3$ & $0 / 3$ \\
\hline & Liver & $2 / 3$ & $2 / 3$ & $0 / 3$ & $0 / 3$ \\
\hline & Heart & $3 / 3$ & $3 / 3$ & $0 / 3$ & $0 / 3$ \\
\hline & Total & $8 / 9$ & $7 / 9$ & $0 / 9$ & $0 / 9$ \\
\hline \multirow{4}{*}{$2^{\text {nd }} w$} & Lung & $2 / 3$ & $1 / 3$ & $0 / 3$ & $0 / 3$ \\
\hline & Liver & $2 / 3$ & $1 / 3$ & $0 / 3$ & $0 / 3$ \\
\hline & Heart & $1 / 3$ & $0 / 3$ & $0 / 3$ & $0 / 3$ \\
\hline & Total & $5 / 9$ & $2 / 9$ & $0 / 9$ & $0 / 9$ \\
\hline \multirow{4}{*}{$3^{\text {rd }} w$} & Lung & $2 / 3$ & $0 / 3$ & $0 / 3$ & $0 / 3$ \\
\hline & Liver & $2 / 3$ & $0 / 3$ & $0 / 3$ & $0 / 3$ \\
\hline & Heart & $1 / 3$ & $0 / 3$ & $0 / 3$ & $0 / 3$ \\
\hline & Total & $5 / 9$ & $0 / 9$ & $0 / 9$ & $0 / 9$ \\
\hline \multirow{4}{*}{$4^{\text {th }} \mathrm{w}$} & Lung & $2 / 3$ & $0 / 3$ & $0 / 3$ & $0 / 3$ \\
\hline & Liver & $1 / 3$ & $0 / 3$ & $0 / 3$ & $0 / 3$ \\
\hline & Heart & $0 / 3$ & $0 / 3$ & $0 / 3$ & $0 / 3$ \\
\hline & Total & $3 / 9$ & $0 / 9$ & $0 / 9$ & $0 / 9$ \\
\hline \multirow{4}{*}{$5^{\text {th }}$} & Lung & $1 / 3$ & $0 / 3$ & $0 / 3$ & $0 / 3$ \\
\hline & Liver & $0 / 3$ & $0 / 3$ & $0 / 3$ & $0 / 3$ \\
\hline & Heart & $0 / 3$ & $0 / 3$ & $0 / 3$ & $0 / 3$ \\
\hline & Total & $1 / 9$ & $0 / 9$ & $0 / 9$ & $0 / 9$ \\
\hline \multicolumn{2}{|c|}{ Total } & $23 / 45$ & $10 / 45$ & $0 / 45$ & $0 / 45$ \\
\hline
\end{tabular}


Table 4: Effect of propolis on phagocytic activity\% and phagocytic index.

\begin{tabular}{|c|c|c|c|c|c|c|c|c|}
\hline \multirow{2}{*}{ Age } & \multicolumn{2}{|c|}{$\mathrm{G} 1($ E. coli $)$} & \multicolumn{2}{|c|}{ G2(E. coli+Propolis) } & \multicolumn{2}{|c|}{ G3(Propolis) } & \multicolumn{2}{|c|}{ G4(control) } \\
\hline & PA & PI & PA & PI & PA & PI & PA & PI \\
\hline $1 \mathrm{w}$ & $43.3 \pm 0.66^{\mathrm{d}}$ & $1.13 \pm 0.67$ & $63.33 \pm 2.16^{c}$ & $3.27 \pm 0.15$ & $81.67 \pm 0.15^{\mathrm{a}}$ & $4.53 \pm 0.15$ & $72 \pm 0.15^{b}$ & $3.9 \pm 0.58$ \\
\hline $2 \mathrm{w}$ & $46 \pm 2^{\mathrm{d}}$ & $1.3 \pm 0.10$ & $65.33 \pm 0.67^{\mathrm{c}}$ & $3.1 \pm 0.10$ & $83 \pm 1.53^{\mathrm{a}}$ & $4.6 \pm 0.12$ & $72.33 \pm 1.45^{\mathrm{b}}$ & $3.88 \pm 0.17$ \\
\hline $3 \mathrm{w}$ & $48 \pm 1.15^{\mathrm{d}}$ & $1.4 \pm 0.58$ & $64 \pm 1.15^{\mathrm{c}}$ & $3.33 \pm 0.03$ & $83 \pm 1.00^{\mathrm{a}}$ & $4.6 \pm 0.1$ & $73.33 \pm 2.40^{\mathrm{b}}$ & $4.02 \pm 0.10$ \\
\hline $4 \mathrm{w}$ & $45 \pm 0.58^{c}$ & $1.25 \pm 0.29$ & $68.67 \pm 0.67^{b}$ & $3.73 \pm 0.33$ & $82.33 \pm 2.19^{a}$ & $4.55 \pm 0.16$ & $74 \pm 2.30^{\mathrm{b}}$ & $4.02 \pm 0.10$ \\
\hline $5 \mathrm{w}$ & $50 \pm 1.15^{c}$ & $1.48 \pm 0.44$ & $71.33 \pm 1.76^{b}$ & $3.97 \pm 0.15$ & $83.67 \pm 0.88^{a}$ & $4.63 \pm 0.88$ & $73.67 \pm 0.88^{b}$ & $3.95 \pm 0.29$ \\
\hline
\end{tabular}

Table 5: Effect of propolis on total and differential leukocytic count.

\begin{tabular}{|c|c|c|c|c|c|}
\hline Age & & G1(E. coli) & G2(E. coli+Propolis) & G3(Propolis) & G4(control) \\
\hline \multirow{6}{*}{$1 \mathrm{w}$} & TLC & $19.5 \pm 0.15^{\mathrm{a}}$ & $19.3 \pm 0.11^{\mathrm{a}}$ & $18.2 \pm 0.89^{b}$ & $16.7 \pm 0.12^{\mathrm{c}}$ \\
\hline & $\mathrm{L}$ & $40.7 \pm 1.20^{\mathrm{c}}$ & $42.7 \pm 0.88^{\mathrm{c}}$ & $52 \pm 1.15^{\mathrm{a}}$ & $46.5 \pm 1.38^{\mathrm{b}}$ \\
\hline & $\mathrm{H}$ & $48.3 \pm 0.33^{\mathrm{a}}$ & $45.7 \pm 0.67^{\mathrm{ab}}$ & $38 \pm 1.73^{\mathrm{c}}$ & $43 \pm 0.58^{b}$ \\
\hline & $\mathrm{M}$ & $5.3 \pm 0.33^{\mathrm{a}}$ & $5.3 \pm 0.67^{\mathrm{a}}$ & $5.7 \pm 0.33^{\mathrm{a}}$ & $5.3 \pm 0.33^{\mathrm{a}}$ \\
\hline & $E$ & $4.3 \pm 0.89^{\mathrm{a}}$ & $4.7 \pm 0.33^{\mathrm{a}}$ & $4 \pm 1.15^{\mathrm{a}}$ & $3.7 \pm 0.33^{\mathrm{a}}$ \\
\hline & $\bar{B}$ & $1.3 \pm 0.33^{\mathrm{a}}$ & $1.7 \pm 0.67^{\mathrm{a}}$ & $1 \pm 0.58^{\mathrm{a}}$ & $1.3 \pm 0.33^{\mathrm{a}}$ \\
\hline \multirow{6}{*}{$2 w$} & TLC & $27.2 \pm 0.13^{\mathrm{a}}$ & $23.4 \pm 0.15^{b}$ & $22.7 \pm 0.12^{\mathrm{c}}$ & $20.4 \pm 0.15^{\mathrm{d}}$ \\
\hline & $\mathrm{L}$ & $36 \pm 1.00^{\mathrm{d}}$ & $44 \pm 1.00^{\mathrm{c}}$ & $53.7 \pm 1.20^{\mathrm{a}}$ & $49.3 \pm 0.88^{\mathrm{b}}$ \\
\hline & $\mathrm{H}$ & $53.3 \pm 0.33^{\mathrm{a}}$ & $47 \pm 1.00^{b}$ & $38.7 \pm 0.88^{\mathrm{c}}$ & $40.7 \pm 1.20^{\mathrm{c}}$ \\
\hline & $\mathrm{M}$ & $5.3 \pm 0.33^{\mathrm{a}}$ & $6 \pm 0.58^{a}$ & $5.7 \pm 0.67^{\mathrm{a}}$ & $5 \pm 0.00^{\mathrm{a}}$ \\
\hline & $E$ & $4.3 \pm 0.33^{\mathrm{a}}$ & $3 \pm 0.58^{\mathrm{ab}}$ & $1.7 \pm 0.33^{b}$ & $4 \pm 1.15^{\mathrm{ab}}$ \\
\hline & $\mathrm{B}$ & $1 \pm 0.58^{\mathrm{a}}$ & $1 \pm 0.58^{\mathrm{a}}$ & $0.3 \pm 0.33^{\mathrm{a}}$ & $1 \pm 0.00^{\mathrm{a}}$ \\
\hline \multirow{6}{*}{$3 w$} & TLC & $30.1 \pm 0.15^{\mathrm{a}}$ & $28.5 \pm 0.20^{\mathrm{b}}$ & $27.7 \pm 0.17^{\mathrm{c}}$ & $25.2 \pm 0.67^{d}$ \\
\hline & $\mathrm{L}$ & $28.7 \pm 0.88^{c}$ & $48.7 \pm 0.88^{b}$ & $53.7 \pm 0.88^{\mathrm{a}}$ & $50.7 \pm 0.88^{b}$ \\
\hline & $\mathrm{H}$ & $59 \pm 0.58^{\mathrm{a}}$ & $42.3 \pm 1.45^{\mathrm{b}}$ & $36 \pm 1.00^{\mathrm{c}}$ & $39.7 \pm 0.88^{b}$ \\
\hline & $\mathrm{M}$ & $4.3 \pm 0.33^{\mathrm{a}}$ & $5 \pm 0.58 \mathrm{a}^{\mathrm{a}}$ & $5.3 \pm 0.33^{\mathrm{a}}$ & $5.3 \pm 0.33^{\mathrm{a}}$ \\
\hline & $E$ & $6 \pm 0.00^{\mathrm{a}}$ & $4 \pm 0.58^{\mathrm{a}}$ & $4 \pm 1.15^{\mathrm{a}}$ & $3.7 \pm 0.88^{\mathrm{a}}$ \\
\hline & $\mathrm{B}$ & $2 \pm 0.58^{\mathrm{a}}$ & $0.7 \pm 0.33^{\mathrm{a}}$ & $0.7 \pm 0.33^{\mathrm{a}}$ & $0.7 \pm 0.33^{\mathrm{a}}$ \\
\hline \multirow{6}{*}{$4 \mathrm{w}$} & TLC & $34.5 \pm 0.21^{\mathrm{a}}$ & $30.1 \pm 0.03^{b}$ & $29.3 \pm 0.12^{\mathrm{c}}$ & $27.4 \pm 0.17^{d}$ \\
\hline & $\mathrm{L}$ & $31.7 \pm 1.45^{\mathrm{b}}$ & $51.7 \pm 0.88^{\mathrm{a}}$ & $54.3 \pm 0.88^{\mathrm{a}}$ & $52 \pm 1.00^{\mathrm{a}}$ \\
\hline & $\mathrm{H}$ & $56 \pm 1.15^{\mathrm{a}}$ & $38.7 \pm 0.33^{b}$ & $34.3 \pm 1.20^{\mathrm{c}}$ & $38.7 \pm 0.88^{b}$ \\
\hline & $\mathrm{M}$ & $4.7 \pm 0.88^{\mathrm{a}}$ & $5 \pm 0.58^{\mathrm{a}}$ & $6 \pm 0.00^{\mathrm{a}}$ & $5 \pm 1.15^{\mathrm{a}}$ \\
\hline & $E$ & $6 \pm 0.58^{\mathrm{a}}$ & $4 \pm 0.58^{\mathrm{a}}$ & $3.7 \pm 1.20^{\mathrm{a}}$ & $4.7 \pm 0.88^{\mathrm{a}}$ \\
\hline & $\mathrm{B}$ & $1.7 \pm 0.88^{\mathrm{a}}$ & $0.7 \pm 0.67^{\mathrm{a}}$ & $1 \pm 0.58^{\mathrm{a}}$ & $1 \pm 0.58^{\mathrm{a}}$ \\
\hline \multirow{6}{*}{$5 \mathrm{w}$} & TLC & $40.1 \pm 0.17^{\mathrm{a}}$ & $32.2 \pm 0.15^{b}$ & $32.1 \pm 0.14^{b}$ & $29.3 \pm 0.58^{c}$ \\
\hline & $\mathrm{L}$ & $35 \pm 2.08^{\mathrm{b}}$ & $52 \pm 1.00^{\mathrm{a}}$ & $54.7 \pm 2.40^{\mathrm{a}}$ & $54.7 \pm 2.19^{a}$ \\
\hline & $\mathrm{H}$ & $53.7 \pm 1.76^{\mathrm{a}}$ & $37.7 \pm 0.88^{b}$ & $36.7 \pm 1.20^{\mathrm{b}}$ & $36 \pm 1.00^{b}$ \\
\hline & $\mathrm{M}$ & $4.7 \pm 0.33^{\mathrm{a}}$ & $5 \pm 0.58^{\mathrm{a}}$ & $5.7 \pm 0.33^{\mathrm{a}}$ & $4.7 \pm 0.88^{\mathrm{a}}$ \\
\hline & $E$ & $5.7 \pm 0.88^{\mathrm{a}}$ & $4.7 \pm 0.88^{\mathrm{a}}$ & $3 \pm 1.15^{\mathrm{a}}$ & $4 \pm 1.00^{\mathrm{a}}$ \\
\hline & $\mathrm{B}$ & $1 \pm 0.58^{\mathrm{a}}$ & $0.7 \pm 0.33^{\mathrm{a}}$ & $0.7 \pm 0.33^{\mathrm{a}}$ & $0.7 \pm 0.33^{\mathrm{a}}$ \\
\hline
\end{tabular}

Data was set as mean \pm Standard error. Means within the same row with different superscripts are significantly different $(P<0.05)$. 


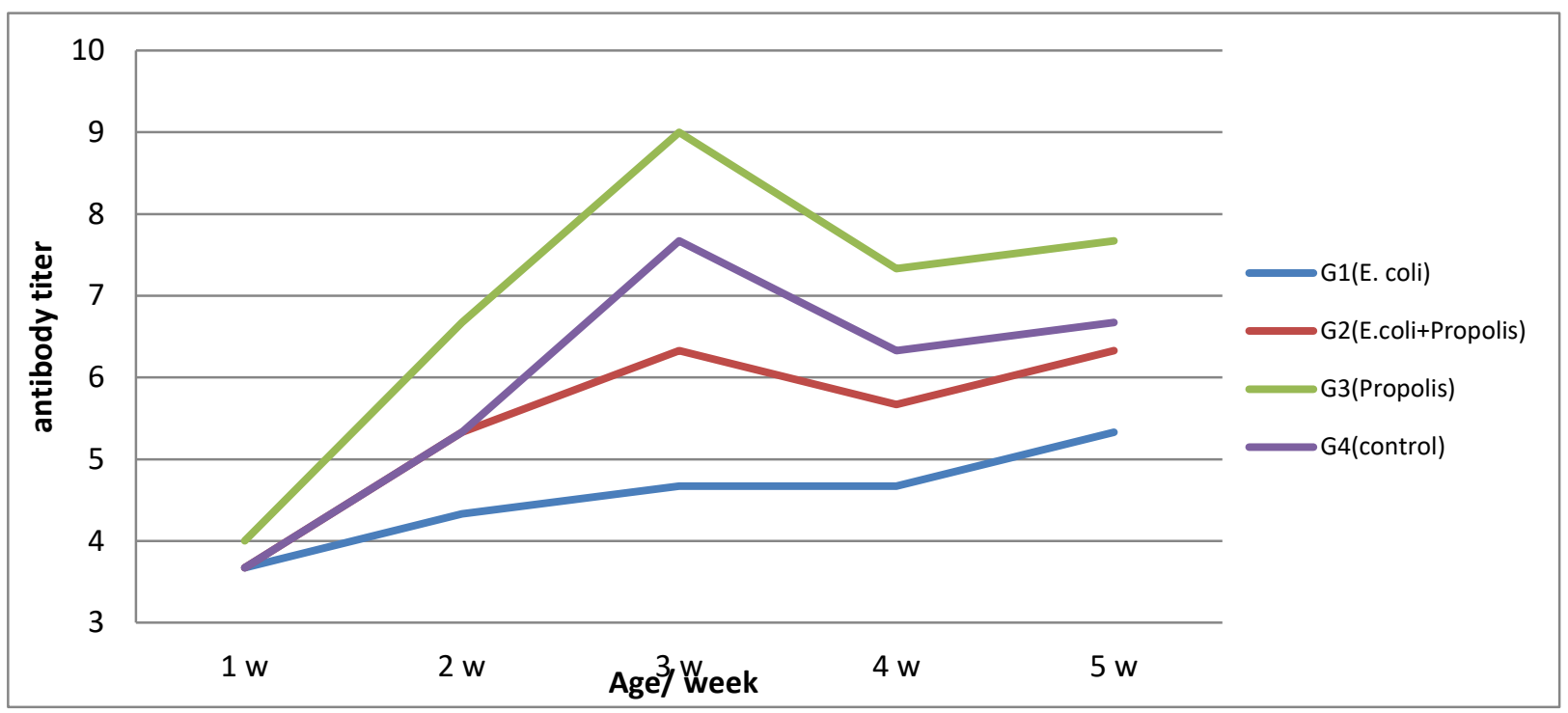

Fig (1): Effect of propolis on antibody titer (log) against Newcastle disease vaccine.

\section{Meat quality}

\section{Chemical composition}

The results displayed in Table (6) indicated that the groups of broiler chicks fed diet supplemented with propolis (G2 and G3) resulted in significantly higher protein $\quad(20.31 \pm 0.1, \quad 22.16 \pm 0.23)$, respectively. There was a non significant difference in moisture content among groups, the highest content was detected in propolis supplemented group (74.6 \pm 1.9$)$ and the lowest in E. coli infected group (74.3 \pm 0.4$)$. Meanwhile, there was a non significant differences of $\mathrm{pH}$ value in between groups. In addition, no significant differences were observed in ash content among dietary groups, with the highest value in E.coli infected group $(1.18 \pm 0.20 \mathrm{~g} .100 \mathrm{~g}-1)$ and the lowest one in propolis supplemented group $(1.05 \pm 0.28 \mathrm{~g} .100 \mathrm{~g}-1)$. Also the significant changes $(p \leq 0.05)$ were observed in fat content between groups, the highest fat content was detected in $E$. coli infected group (G1) by $(1.8 \pm 0.75)$ and lowest was detected in propolis supplemented group (G3) by $(0.84 \pm 0.12)$ when compared to the control one.

\section{Microbial evaluation:}

As shown in Table (7) using of propolis in boiler chicken feed significantly $(\mathrm{P}<0.05) \quad$ reduced coliform, Staphylococci and Psycrotrophic bacteria in chicken's breast muscle in propolis supplemented groups (G2 and G3) when compared to E. coli infected and control group (G1 and G4) respectively. Propolis supplemented group showed the lowest Agar Plate count among groups $(5.97 \pm 0.18) \quad \log \quad \mathrm{cfu} / \mathrm{g}$. Enterobacteriaceae count was significantly decreased in propolis supplemented group (3.42 \pm 0.14$) \quad \log$ $\mathrm{cfu} / \mathrm{g}$ when compared to other groups.

\section{Sensory evaluation:}

Table (8) represented the scores given by panelists for the sensory characteristics (color, flavor, juiciness, tenderness, and overall acceptability) of breast chicken meat. There was significant effects $(\mathrm{P} \leq 0.05)$ of propolis supplementation on the sensory attributes. The highest scores for overall acceptability was given for propolis supplemented group (4.26 \pm 0.29 ) which considered as the most 
acceptable for panelists and E. coli infected group (G1) has received the lowest score (3.26 \pm 0.18$)$ when compared to control group. As for the color, all the groups differ from each other, with the highest mean score found in propolis supplemented group $(4.5 \pm 0.36)$ and the lowest score was found in $E$. coli infected group (3.62 \pm 0.27 ). Also for flavor there was significant difference $(\mathrm{P} \leq 0.05)$ between (G2 and G3) and (G1 and G4). For tenderness, lowest score was detected in the Eoli infected group (3.2 \pm 0.21$)$.
Statistically significant differences $(\mathrm{P} \leq 0.05)$ were detected between mean scores for (G2 and G3) and those for G1 and $\mathrm{G} 4$ group. In terms of juiciness, the highest score observed in G3 (4.38 \pm 0.31 ). This means that after application of the propolis in the diet of chickens were found improved organoleptic properties of the breast muscle. However, panelists were unable to differentiate tenderness of chicken breast meat from groups $\mathrm{G} 2$ and $\mathrm{G} 3$, as well as juiciness of meat from groups $\mathrm{G} 2$ and $\mathrm{G} 3$.

Table 6: Effect of propolis on chemical composition of broiler breast samples (\%).

$$
\text { G1(E. coli) G2(E. coli+Propolis) G3(Propolis) G4(control) }
$$

\begin{tabular}{ccccc}
\hline Protein & $19.35 \pm 0.35^{\mathrm{c}}$ & $20.31 \pm 0.1^{\mathrm{b}}$ & $22.16 \pm 0.23^{\mathrm{a}}$ & $20.24 \pm 0.25^{\mathrm{b}}$ \\
\hline Fat & $1.8 \pm 0.75^{\mathrm{a}}$ & $1.36 \pm 0.43^{\mathrm{b}}$ & $0.84 \pm 0.12^{\mathrm{c}}$ & $0.92 \pm 0.05^{\mathrm{c}}$ \\
\hline Ash & $1.18 \pm 0.20^{\mathrm{a}}$ & $1.15 \pm 0.1^{\mathrm{a}}$ & $1.05 \pm 0.28^{\mathrm{a}}$ & $1.08 \pm 0.46^{\mathrm{a}}$ \\
\hline PH & $5.9 \pm 0.057^{\mathrm{a}}$ & $6.01 \pm 0.12^{\mathrm{a}}$ & $5.94 \pm 0.17^{\mathrm{a}}$ & $5.92 \pm 0.05^{\mathrm{a}}$ \\
\hline Moisture & $72.03 \pm 0.89^{\mathrm{a}}$ & $74.3 \pm 0.43^{\mathrm{a}}$ & $74.6 \pm 1.9^{\mathrm{a}}$ & $74.01 \pm 0.2^{\mathrm{a}}$
\end{tabular}

Data was set as mean \pm Standard error. Means within the same row with different superscripts are significantly different $(P<0.05)$.

Table 7: Effect of propolis on the microbial count $(\log \mathrm{cfu} / \mathrm{g})$ of broiler breast samples.

\begin{tabular}{ccccc}
\hline & G1 $($ E. coli) & G2(E. coli+Propolis) & G3(Propolis) & G4(control) \\
\hline Total APC counts & $7.26 \pm 0.39^{\mathrm{a}}$ & $6.26 \pm 0.26^{\mathrm{ab}}$ & $5.97 \pm 0.18^{\mathrm{b}}$ & $6.59 \pm 0.95^{\mathrm{ab}}$ \\
\hline Total Coliform & $4.08 \pm 0.07^{\mathrm{a}}$ & $3.4 \pm 0.99^{\mathrm{b}}$ & $3.12 \pm 0.91^{\mathrm{b}}$ & $3.84 \pm 0.87^{\mathrm{a}}$ \\
\hline $\begin{array}{c}\text { Total } \\
\text { Enterobacteriaceae }\end{array}$ & $3.99 \pm 0.05^{\mathrm{a}}$ & $3.88 \pm 0.09^{\mathrm{a}}$ & $3.42 \pm 0.14^{\mathrm{b}}$ & $4.04 \pm 0.15^{\mathrm{a}}$ \\
\hline $\begin{array}{c}\text { Total } \\
\text { Staphylococci } \\
\text { count }\end{array}$ & $4.55 \pm 0.19^{\mathrm{a}}$ & $3.46 \pm 0.16^{\mathrm{b}}$ & $3.33 \pm 0.18^{\mathrm{b}}$ & $4.52 \pm 0.28^{\mathrm{a}}$ \\
\hline $\begin{array}{c}\text { Total } \\
\text { Pscychrotrophic }\end{array}$ & $5.12 \pm 0.05^{\mathrm{a}}$ & $4.34 \pm 0.19^{\mathrm{b}}$ & $4.57 \pm 0.02^{\mathrm{b}}$ & $5.23 \pm 0.04^{\mathrm{a}}$ \\
\hline $\begin{array}{l}\text { Data was set as mean } \pm \text { Standard error. Means within the same row with different superscripts } \\
\text { are significantly different }(P<0.05) .\end{array}$ & &
\end{tabular}


Table 8: Effect of propolis on sensory evaluation of chicken breast meat.

\begin{tabular}{ccccc}
\hline Groups & G1 $($ E. coli $)$ & G2(E. coli+Propolis) & G3(Propolis) & G4(control) \\
\hline Color & $3.62 \pm 0.27^{\mathrm{b}}$ & $4.2 \pm 0.21^{\mathrm{a}}$ & $4.5 \pm 0.36^{\mathrm{a}}$ & $3.78 \pm 0.22^{\mathrm{b}}$ \\
\hline Flavor & $3.42 \pm 0.37^{\mathrm{b}}$ & $4.1 \pm 0.42^{\mathrm{a}}$ & $4.44 \pm 0.28^{\mathrm{a}}$ & $3.6 \pm 0.26^{\mathrm{b}}$ \\
\hline Juiciness & $3.22 \pm 0.19^{\mathrm{c}}$ & $3.64 \pm 0.4^{\mathrm{b}}$ & $4.38 \pm 0.31^{\mathrm{a}}$ & $3.24 \pm 0.23^{\mathrm{c}}$ \\
\hline Tenderness & $3.2 \pm 0.21^{\mathrm{c}}$ & $3.76 \pm 0.32^{\mathrm{b}}$ & $4.26 \pm 0.29^{\mathrm{a}}$ & $3.44 \pm 0.27^{\mathrm{ab}}$ \\
\hline $\begin{array}{c}\text { Overall } \\
\text { acceptability }\end{array}$ & $\mathbf{3 . 2 6} \pm \mathbf{0 . 1 8}^{\mathrm{c}}$ & $\mathbf{3 . 8} \pm \mathbf{0 . 2 5}^{\mathrm{b}}$ & $\mathbf{4 . 2 6} \pm \mathbf{0 . 2 9}^{\mathrm{a}}$ & $\mathbf{3 . 6 9} \pm \mathbf{0 . 4 5}^{\mathbf{c}}$ \\
\hline
\end{tabular}

Data was set as mean \pm Standard error. Means within the same row with different superscripts are significantly different $(P<0.05)$.

\section{Histopathological changes:}

\section{Heart:}

In control group, heart displayed normal myocardium with normal cardiac muscle fiber striations (Fig.2A). Heart in E. coli infected group showed severe degeneration of myocardial muscle (myopathy), loss of striations of muscle fibres, revealed eosinophilic necrotic area with leucocytic infiltration, predominantly heterophils in myocardium and hemorrhage (Fig.2B). In propolis supplemented group, heart showed normal myocardium and normal cardiac muscle fibers (Fig.2C). E. coli-propolis supplemented group, showed normal cardiac muscle striations, moderate edema and accumulation of heterophils were also observed (Fig.2D).
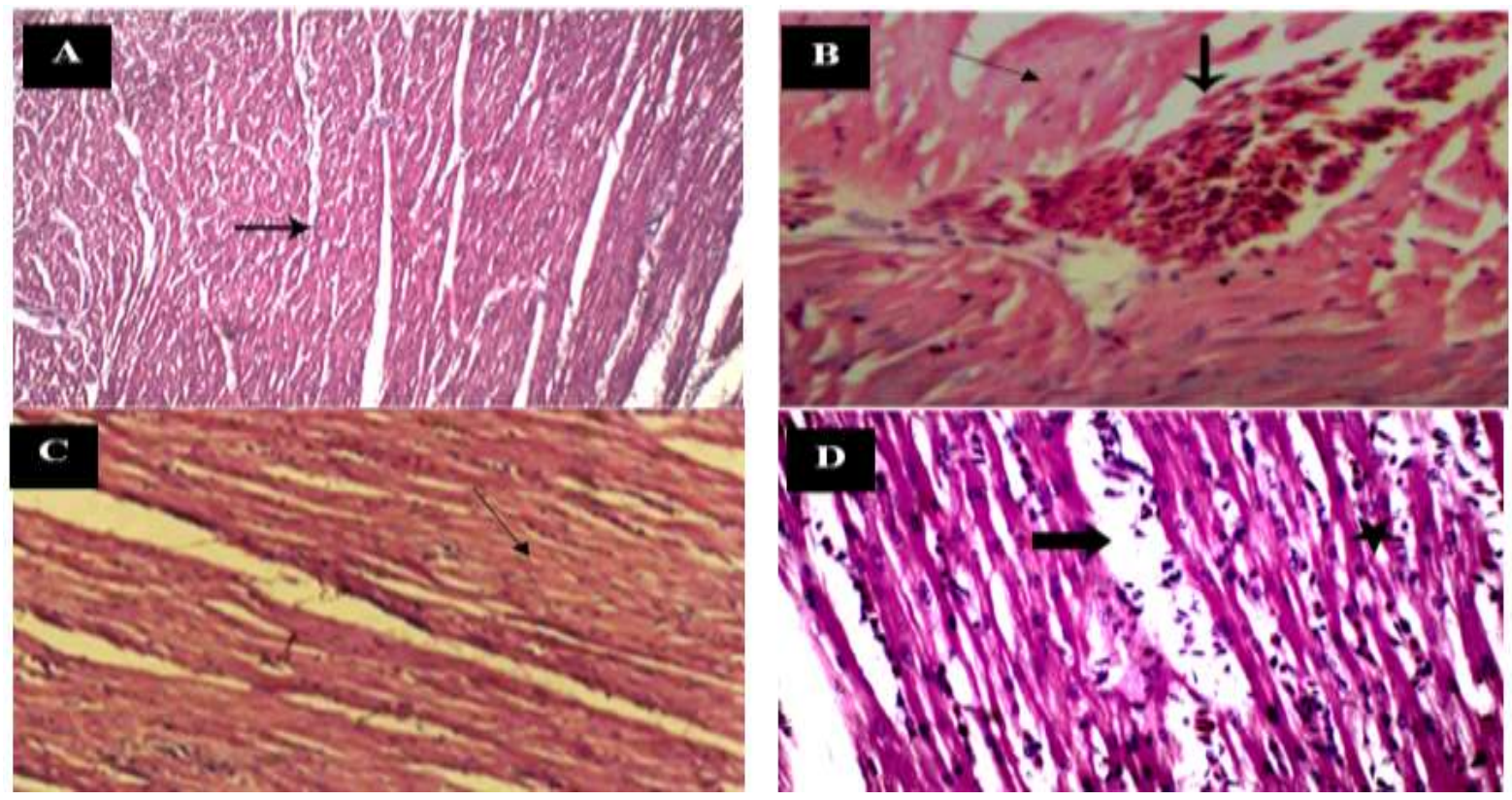

Figure (2): Histopathological changes in heart in different groups

A: Control group showing normal myocardium with normal cardiac muscle fiber striations (arrow).HE, 100x.

B: E. coli infected group showing severe degeneration of myocardium, loss of striations of muscle fibres (thin arrow), diffuse heterophilic aggregation in myocardium and hemorrhage (thick arrow). HE, 100x.

C: Propolis supplemented group showing normal myocardium, normal cardiac muscle fibers (arrow).HE, 100x.

D: E. coli-propolis supplemented group showing normal cardiac muscle fibers (star), moderate edema and heterophilic aggregation (arrow).HE, 100x. 


\section{Lungs:}

Lung in control group showed normal hexagonal shape parabronchi lined with squamous epithelium, its wall has numerous openings leading to respiratory atria and air capillaries. Each parapronchi separated from adjacent lobules by fibrous septa and capillaries (Fig.3A). In E. coli infected group, there was marked degeneration of parenchyma characterized by strongly stained eosinophilic zone surrounding the parabronchi, besides haemorrhage and edema in the interalveolar septa. Also, most of parabronchi was ringed due to swelling of lining epithelium and filled with eosinophilic exudates with granulocytes aggregations in bronchial epithelium marked obliteration of pulmonary capillary (Fig.3B). Propolis supplemented group showed normal parabronchi without any exudates, and intact lining epithelium. The interalveolar septa were prominent with normal capillaries (Fig.3C). E. coli-propolis supplemented group showed swelling of atrial lining cells, besides mild infiltration of heterophils in parabronchial lumen and respiratory atria. The septa among parabronchi were distended with engorged capillaries (Fig.3D).
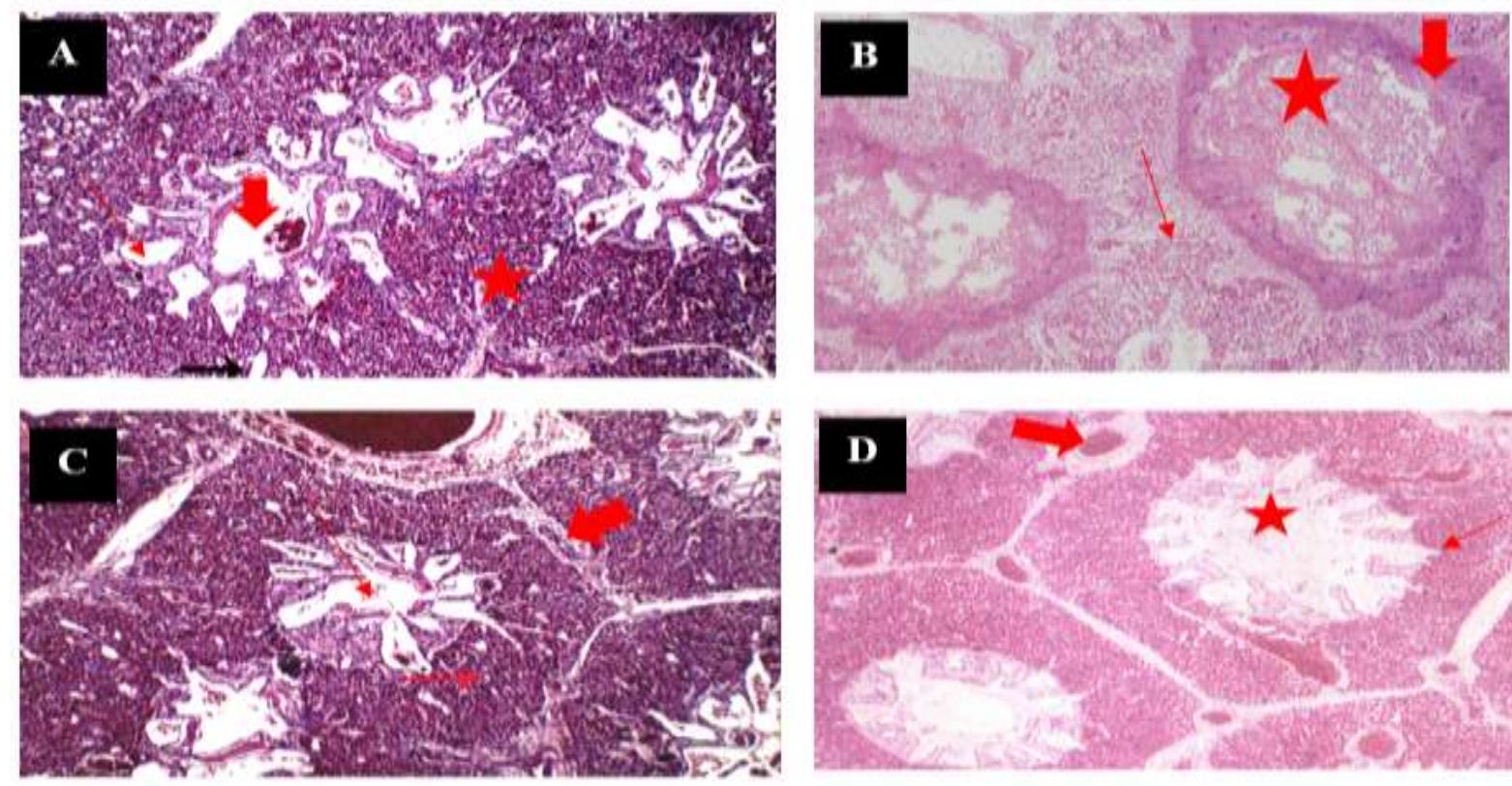

Figure (3): Histopathological changes in lung in different groups.

A: control group showing normal hexagonal shape parabronchi lined with squamous epithelium (thick arrow), leading to normal respiratory atria (thin arrow), and separated by fibrous septa with blood capillaries (star). HE, 400x.

B: E. coli infected group showing degenerated parabronchi surrounded by eosinophilic zone (thick arrow) and filled with intense exudate and granulocytes aggregation (star), hemorrhage and diffuse edema in the inter alveolar septa (thin arrow), HE, 400x.

C: propolis supplemented group showing normal parabronchi and atria with intact lining epithelium (arrows), prominent interalveolar septa and normal capillaries (thick arrow). HE, 400x.

D: E. coli-propolis supplemented group showing swelling of atrial lining cells (thin arrow), mild infiltration of heterophils in parabronchial lumen and respiratory atria (star), distended septa with engorged capillaries (thick arrow). HE, 400x. 


\section{Liver:}

In the control group, the liver tissue displayed normal parenchyma with hepatocytes arranged in radiating cords toward the central vein (Fig.4A). In E. coli infected group, Liver showed, Congestion of blood vessels and hemorrhages, hepatic vacuolar degeneration besides focal coagulative necrosis and heterophilic
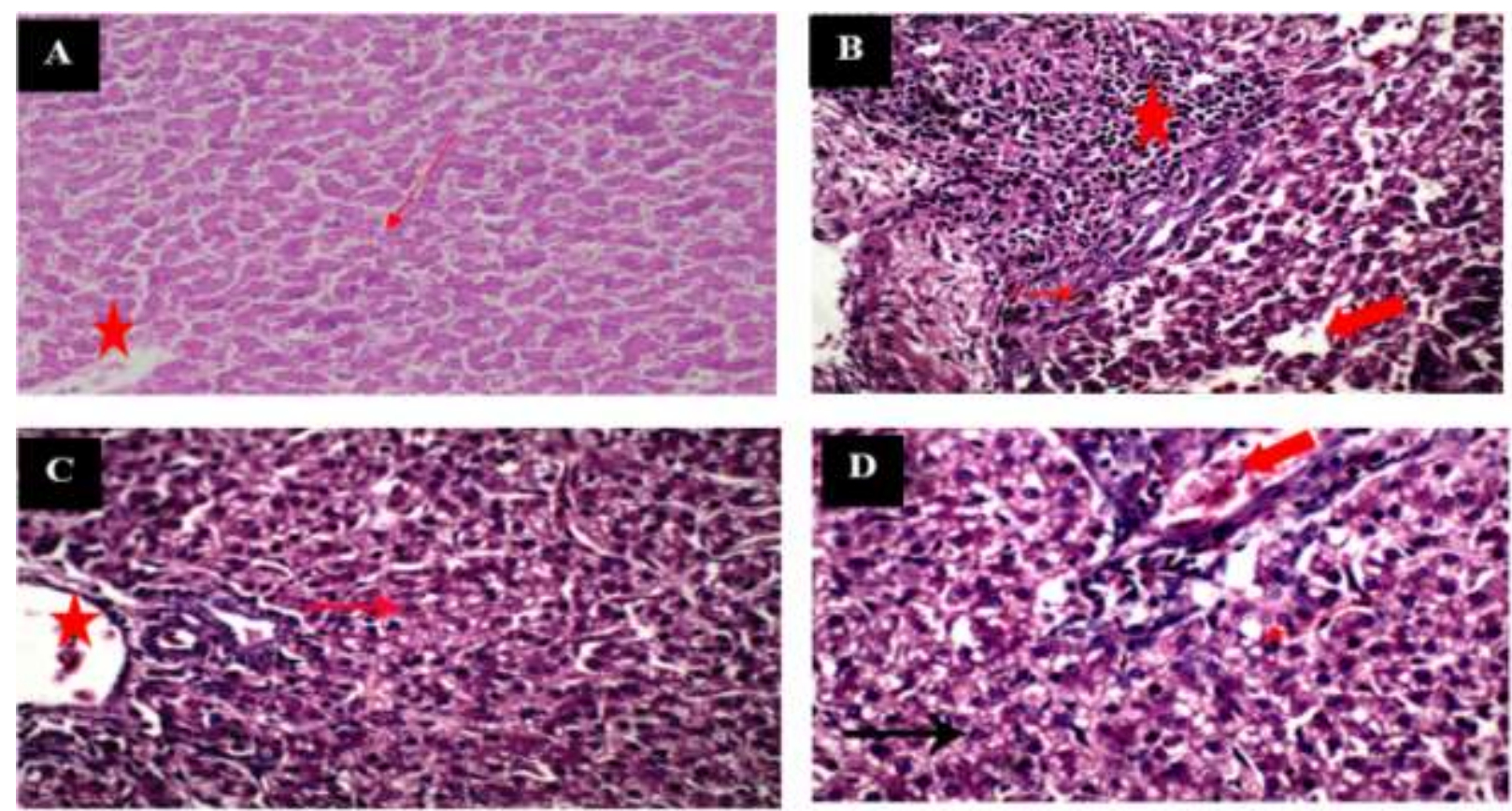

Figure (4): Histopathological changes in liver in different groups

A: Control group showing normal parenchyma with hepatocytes arranged in radiating cords. HE, 100x.

B: E. coli infected group showing hepatic vacuolar degeneration (thick arrow), focal coagulative necrosis (thin arrow) and heterophilic aggregation (star). HE, 100x.

C: Propolis supplemented group showing normal hepatic tissue, with dialated hepatic central vein (star). HE, 100x.

D: E. coli-propolis supplemented group showing mild congestion, perivascular inflammatory cells infiltration (thick arrow) mild vacular degeneration (thin arrow). HE, 100x.

\section{Intestine:}

In the control group, Intestine showed normal intestinal villi with intact lining epithelium (Fig.5A). E. coli infected group showed severe villus destruction and lymphocytic aggregation in intestinal lumen (Fig. 5B). Propolis supplemented group, showed increase in the absorptive area of intestine by increase the villus width and length with intact lining epithelium and goblet cell hyperplasia (Fig.5C). The intestine of E. coli-propolis supplemented group showed mild epithelium desquamation and hyperplasia of intestinal glands (Fig.5D). 

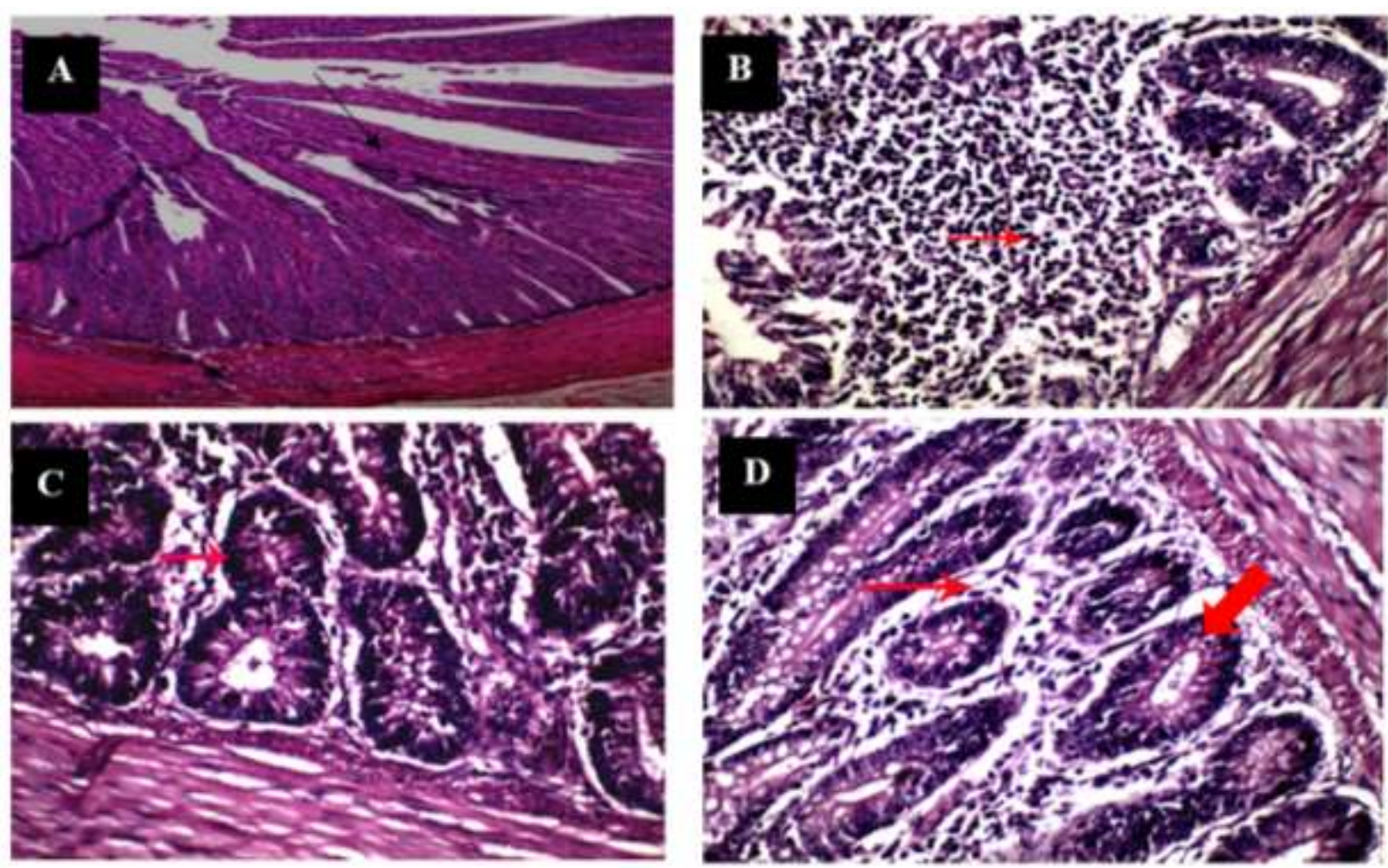

Figure (4): Histopathological changes of intestine in different groups

A: control group showing normal intestinal villi with intact lining epithelium (arrow). HE, $100 x$.

B: E. coli infected group showing severe villus destruction and necrosis with lymphocytic aggregation in intestinal lumen (arrow). HE, 400x.

C: propolis supplemented group showing increase the villus width and length with intact lining epithelium (thick arrow) and goblet cell hyperplasia (thin arrow). HE, 400x.

D: E. coli-propolis supplemented group showing hyperplasia of intestinal glands with (thick arrow) mild epithelial desquamation and lymphocytic aggregation (thin arrow). HE, 400x.

\section{Bursa of Fabricius:}

In the control group, bursa composed of tightly packed lymphoid follicles which consist of cortex and medulla. Follicles separated by connective tissue and covered with pseudostratified columnar epithelium (Fig.6A). E. coli infected group showed lymphocytolysis characterized by severe depletion and lysis of lymphoid cells, associated with appearance of multiple epithelial cysts and edema of subfollicular epithelium and in interfollicular connective tissue (Fig.6B). Propolis supplemented group showed intact surface epithelium, normal lymphoid tissue of cortex and medulla, normal interfollicular and subepithelial connective tissue (Fig.6C). E. colipropolis supplemented group showed mild focal lymphoid deplesion, mild subepithelial and inter follicular congestion and edema with small cyst formation (Fig.6D). 

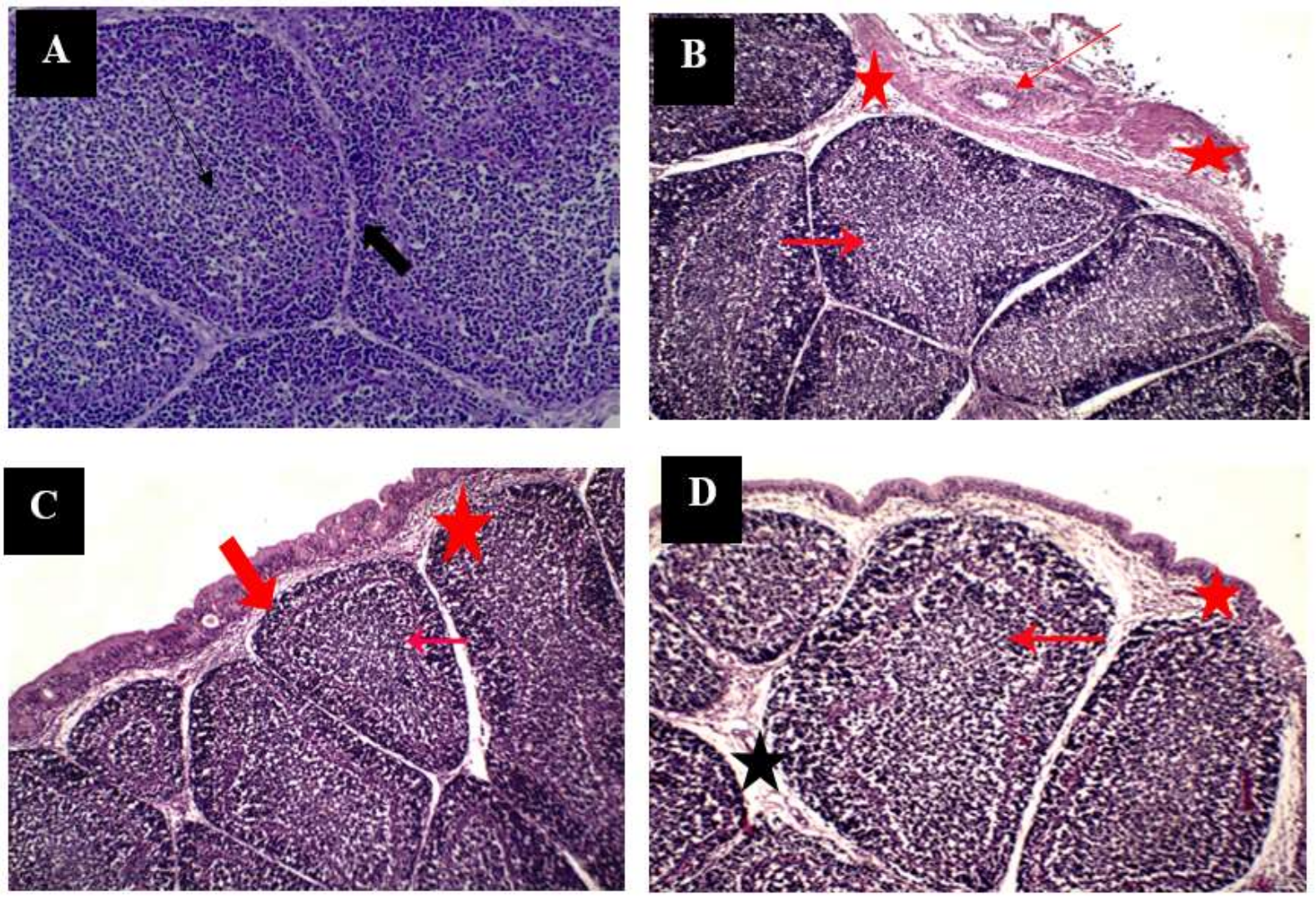

Figure (6): Histopathological changes of Bursa of Fabricius in different groups

A: control group showing tightly packed lymphoid follicles consist of cortex and medulla (thin arrow), Separated by connective tissue (thick arrow) and covered with pseudostratified columnar epithelium (HE, 100x).

B: E. coli infected group showing severe lymphoid depletion and lymphocytolysis (thick arrow), multiple epithelial cysts (thin arrow), and oedema and congestion of follicular surface epithelium and in interfollicular connective tissue (star). HE, 100x.

C: propolis supplemented group showing intact surface epithelium (star), normal cortical and medullary lymphoid tissue (thin arrow) and normal subepithelial and interfollicular connective tissue (thick arrow). HE, 100x.

D: E. coli-propolis supplemented group showing mild focal lymphoid deplesion (arrow), mild subepithelial congestion and oedema, small cyst formation (star). HE, 100x.

\section{Immunohistochemistry of CD79 in bursa and spleen and CD3A in thymus:}

The immune reactive CD79A positive cells in the spleen and bursa showed a significant increase in propolis supplemented groups (G2 and G3) when compared to the corresponding groups (G1 and G4). Detection of CD3A positive cytoplasmic reaction in the thymus showed a significant increase in propolis supplemented groups (G2 and G3) in comparison to the corresponding groups (G1 and G4). E.coli infected group showed a significant decrease of immune cells when compared to other groups (G2, G3, and G4). Fig.7 


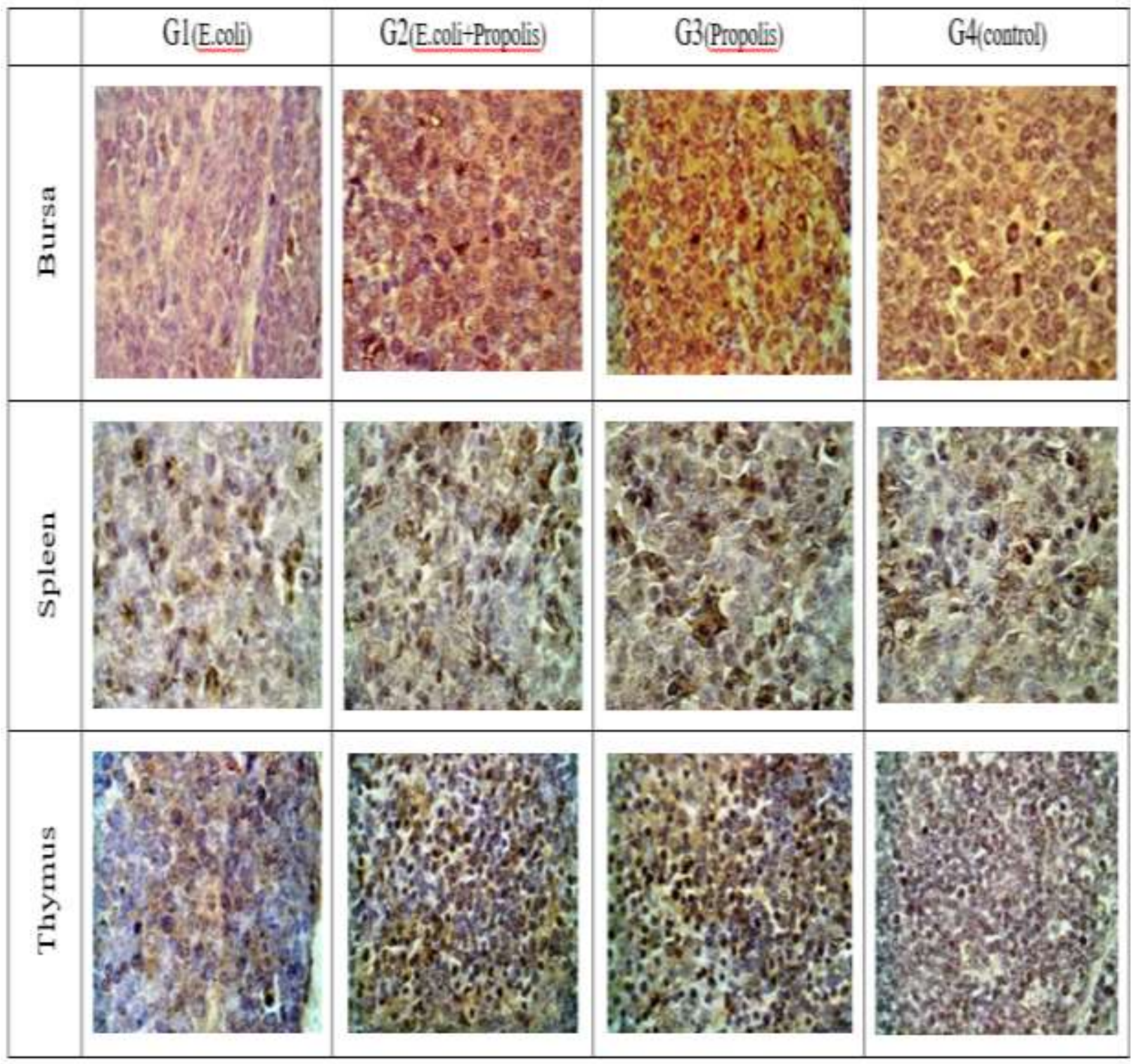

Fig. 7: Immunohistochemistry of CD79 in bursa and spleen and CD3A in thymus:

Table 9: Number of possitive cells, CD79A in bursa and spleen, and CD3A in thymus.

\begin{tabular}{lcccc}
\hline & G1(E.coli) & G2(E.coli+Propolis) & G3(Propolis) & G4(control) \\
\hline CD79A in bursa & $37.6 \pm 3.25^{\mathrm{d}}$ & $65.8 \pm 2.41^{\mathrm{b}}$ & $88.4 \pm 8.71^{\mathrm{a}}$ & $62.5 \pm 2.75^{\mathrm{c}}$ \\
\hline CD79A in spleen & $29.4 \pm 8.21^{\mathrm{d}}$ & $58.21 \pm 7.3^{\mathrm{b}}$ & $79.3 \pm 2.01^{\mathrm{a}}$ & $56.15 \pm 3.36^{\mathrm{c}}$ \\
\hline CD3A in thymus & $32.4 \pm 8.63 \mathrm{~d}$ & $47.3 \pm 4.1 \mathrm{~b}$ & $69.5 \pm 5.23 \mathrm{a}$ & $45.32 \pm 3.73 \mathrm{c}$ \\
\hline
\end{tabular}

Data was set as mean \pm Standard error. Means within the same row with different superscripts are significantly different $(P<0.05)$. 


\section{DISCUSSION}

Propolis is a highly nutritive material containing vitamins, minerals and other chemicals. The present study was done to evaluate propolis as a feed additive to decrease the adverse effect of collibacillosis instead of using antibiotics. In this study E. coli caused $26.6 \%$ mortality, sever clinical signs that extends for 2 weeks after infection and sever postmortem lesions. Similar results were obtained by Kumari et al. (2020) and Hams and Waleed (2018) whom recorded a mortality rate of $25.7 \%$ and $25 \%$, respectively when infect 7 days old broilers with E. coli. Several studies had recorded the ability of propolis to increase the survival rate of broilers. Klaric et al. (2018) found that the addition of propolis $(0.5 \mathrm{~g} / \mathrm{kg}$ diet $)$ resulted in significant decrease in the mortality rate $(0 \%)$ when compared non supplemented group (10\%). Also, Shalmany and Shivazad (2006) and Omar et al. (2002) recorded much lower mortality in broilers supplemented with propolis.

The positive effect of propolis in decreasing the mortality $(6.6 \%)$, severity of clinical signs and postmortem lesion and shortening of the duration of collibacillosis in E. coli-propolis supplemented group may be due to its powerful bactericidal properties. The Egyptian, Spanish and Greece propolis have the highest antimicrobial activity against $E$. coli when compared to Chinese, Bulgarian, Australian, Italian and Canadian propolis (Hegazi et al., 2014). Dakahlia propolis showed the highest antibacterial activity against $E$. coli when compared to Ismailia and Sharkia propolis (Abd El Hady and Hegazi 2002). The positive effect of propolis may also be attributed to its ability to stimulate the immune system, improve macrophage activity and the functions of the lymphatic tissues (Cetin et al., 2010, Freitas et al., 2011, Shihab and Ali, 2012). Several previous studies on animals have showed that propolis or its flavonoids activate macrophages, increasing phagocytic capability and the release of microbicidal agents, such as nitric oxide and tumour necrosis factor- $\alpha$ (Orsi et al., 2000; Sforcin, 2007). propolis also enhance the resistance of chickens which lead to reduce mortality (Omar et al., 2002; Shalmany and Shivazad, 2006).

E. coli caused a significant decrease in body weight when compared to control all over the experimental period, similar result was obtained by Kumari et al. (2020) when infect 7 days old chicks. The E. coli-propolis supplemented group showed a non significant increase in body weight during the $1^{\text {st }}$ and $2^{\text {nd }}$ week of age and after that showed a significant increase in body weight when compared to $E$. coli infected group which attributed to the antibacterial effect of propolis and early recovery of infection. Propolis had a significant effect on body weight and feed intake in propolis supplemented group. Klaric et al. (2018) reported a significant increase in average body weights of chickens supplemented with $0.5 \mathrm{~g}$ and $1 \mathrm{~g}$ propolis $/ \mathrm{kg}$ feed mixture all over the experimental period while Hassan et al. (2018) indicated that addition of $1 \mathrm{gm}, 2 \mathrm{gm}$ and $3 \mathrm{gm}$ of propolis/ $\mathrm{kg}$ of broiler diet had non significant effect on body weight until the $2^{\text {nd }}$ week of age, which increased significantly from the $3^{\text {rd }}$ week to the $6^{\text {th }}$ week of age. A dose response effect of propolis on body weight was reported where the body weight was significantly 
improved by increasing the dose of propolis in feed at 50, 100, 150, 200 and $250 \mathrm{mg} / \mathrm{kg}$ diet (Shalmany and Schivazad, 2006).

Propolis improved the feed intake in propolis supplemented group in comparison to control group, but did not affect the FCR. An improvement in feed intake and FCR in chickens received 250 $\mathrm{mg}$ and $400 \mathrm{mg}$ of propolis was reported by Shalmany and Schivazad (2006) and Hassan and Abdulla (2011). On the other hand, Mahmoud et al. (2013) found that inclusion of different doses in broiler diet did not affect feed intake and FCR and significantly reduced body weight in comparison to control diet and had adverse effect on performance. Propolis improved both feed intake and FCR in $E$. coli-propolis supplemented group when compared with E. coli infected non supplemented group. Addition of propolis $1 \mathrm{gm} / \mathrm{kg}$ of diet caused an improvement in feed intake and FCR in chickens exposed to lead toxicity and in laying hens reared under chronic heat stress (Tatli and Seven., 2008; Seven et al., 2011; Sevens et al., 2012). The improvement in feed intake and FCR was associated with enhanced flavor due to flavonoid content of propolis and improved digestion and nutrient absorption and metabolism leading to changes in blood concentrations of cholesterol, total protein, and amino acid (Tekeli et al., 2011; Abd El-Rahman and Mosaad, 2013; Attia et al., 2014).

Propolis decreased the reisolation frequency of $E$. coli from internal organs and caused early clearance of infection, where $E$. coli cannot be reisolated after $2^{\text {nd }}$ week of age in $E$. coli-propolis supplemented group while still reisolated at the $5^{\text {th }}$ week of age in $E$. coli infected group. Kumari et al. (2020) isolated E. coli from liver until 28 days post infection. The lower frequency of reisolation and early clearance of infection in infected supplemented group reflects the antibacterial activity of propolis. Several researchers reported the invitro antibacterial activity of propolis on E. coli (Abd El Hady and Hegazi 2002; Hegazi et al., 2014). Propolis showed bacteriostatic activity against wide range of bacterial genera and possess a bactericidal activity in high concentrations (Mirzoeva et al., 1997 and Drago et al., 2000). Antibacterial properties of flavonoids occurs by interfering bacterial cell wall permeability and interaction with bacterial DNA (Bryan, 1982; Wilson and Gisvold, 1982). The antimicrobial activity of propolis is related to the synergistic effect of its compounds (Santos et al., 2002).

Phagocytosis is essential for macrophage to remove invades and present antigens to $\mathrm{T}$ cells so it affects the cellular and humoral immunity (Yang et al., 2014). The effect of $E$. coli infection on phagocytic activity was reported by Hams and waleed (2018), E. coli caused a significant decrease in the phagocytic activity at the $2^{\text {nd }}$ and $3^{\text {rd }}$ week of age after infection of 7 days old chicks. Propolis improved significantly the phagocytic activity in both supplemented groups. Several authors have documented the role of propolis in improving the phagocytic activity (Eyng et al., 2013; Attia et al., 2017). Phagocytic activity was significantly enhanced by propolis flavonoids and tended to be a dose dependent (Yang et al., 2014).

E. coli infection caused leukocytosis with lymphocytopenia and heterophilia. 
Similarly, Umar et al. (2020) found a significant increase in the mean values of leukocytes and significantly increased heterophils with concurrent decrease in lymphocyte count in $E$. coli naturally infected birds when compared to age matched non infected birds. Tandal et al. (2019) revealed leukocytosis at $1^{\text {st }}, 2^{\text {nd }}$ and $3^{\text {rd }}$ week post $E$. coli infection, heterophilia and significant decrease in lymphocytes at $1^{\text {st }}$ and $2^{\text {nd }}$ weeks post infection. Leukocytosis and heterophilia in $E$. coli infected birds could be due to subsequent inflammatory response to $E$. coli induced tissue damage (Patil, 2018). E. coli can induce marked lymphocyte depletion from bursa and thymus (Nakamura et al., 1990).

Propolis caused leukocytosis with significant increase in lymphocytes and significant decrease of heterophils. Attia et al. (2017) found that propolis significantly increased the leukocytes, lymphocytes, heterophil while decreasing $\mathrm{H} / \mathrm{L}$ ratio when administered in poultry feed continuously or intermittently. Propolis supplementation significantly increased lymphocytes and significantly decreased heterophils and $\mathrm{H} / \mathrm{L}$ ratio in broiler chickens and laying hens (Ziaran et al., 2005; Galal et al., 2008). Propolis has anabolic effect, stimulate immune response, activate mitosis, promotes lymphocyte proliferation and enlarge immune organs (Fan et al., 2013; Giuragea et al., 1981). On the other hand, Eyng et al. (2013) and Hassan et al. (2018) observed no differences in the number of lymphocytes, Heterophils, basophils and monocytes or $\mathrm{H} / \mathrm{L}$ ratio at 21 and 42days after propolis supplementation at different doses in chicken feed.
In the current study, E. coli infection caused a significant decrease in the Newcastle antibody titer during the $3^{\text {rd }}$, $4^{\text {th }}$ and $5^{\text {th }}$ week of age. A higher Newcastle antibody titer was observed in vaccinated non infected birds when compared to vaccinated and E. coli infected one (Hegazy et al., 2010; Hassanin et al., 2014; Awad et al., 2019). These results confirmed the immune suppressive effect of E. coli. Propolis supplementation increased the Newcastle antibody titer all over the experimental period while a significant increase was seen at the $2^{\text {nd }}$ and $3^{\text {rd }}$ week only in propolis supplemented group and at the $3^{\text {rd }}$ week of age in E. coli-propolis supplemented group. (Eyng et al., 2013; Eyng et al., 2015) found that supplementation of propolis did not influence the antibody titer against Newcastle disease vaccine while Mohamed et al. (2019) reported a significant increase in serum antibody titer in propolis supplemented group at $21,28,35$, and 42 days of age. Supplementation of propolis continuously or intermittently in poultry feed significantly increase the antibody titter against Newcastle disease vaccine (Attia et al., 2017). Wang et al. (2004) and Taheri et al. (2005) reported the significant effect of propolis on serum antibody titer against NDV, AIV and IBDV and suggested that propolis may have a positive effect on humoral immunity.

As has been shown by this study, propolis supplementation was the most favorable among the groups either infected or not with highest protein content and the lowest fat content in the breast muscle when compared to control group. This agreed with Haščik et al. (2016) who reported high protein content 
$(22.33 \pm 0.58 \%)$ in breast muscle of broiler fed propolis $400 \mathrm{mg} / \mathrm{kg}$ of diet. El-Saadany (2017) mentioned that the beneficial effects of propolis on protein fractions may be due to its stimulating effect on the liver exhibiting an anabolic action favoring protein synthesis and its preserving effect to the body protein from degeneration. Also, it indicates a better retention of minerals $(\mathrm{Ca}, \mathrm{P})$, nitrogen and improved protein efficiency ratio (Khaksefidi, 2005).

Normal $\mathrm{pH}$ values were detected in all groups ranged from 5.76-6.50 and there were no significant difference between groups. Normal $\mathrm{pH}$ indicate the good quality of the chicken meat since the $\mathrm{pH}$ values were not below 5.4 and not above 7.0 when autolysis of meat appeared ,these results are all in agreement with those obtained by Gunya et al. (2019). $\mathrm{pH}$ has an effect on other attributes of meat such as color (Drażbo et al., 2019), texture (Toomer et al., 2019), shelf life, and loss during thermal processing (Janković et al., 2020).

As seen there was an increase on the moisture content of breast muscles in G2and G3 groups when compared to G1 and G4 groups. The moisture content is considered an important factor for product sensory characteristics and this agreed with Rabie et al. (2018) who reported high moisture content in breast muscle for broiler fed propolis 400 $\mathrm{mg} / \mathrm{kg}$ diet by $(78.3 \pm 0.9)$ and Haščík et al. (2016). The data on chemical composition of chicken breast meat were similar to those reported in previous studies, where various supplements were use. However, the data have shown positive effect of propolis on the chemical composition in breast muscle of the investigated parameters (in both propolis-supplemented groups) than those in the Ecoli infected and control groups.

Bacterial contamination of broiler meat is mainly confined to the skin and/ or visceral cavity which occurs during washing, plucking and evisceration. Different bacterial genera were recovered from broiler meat (Odetunde et al., 2011). The colonization pattern of the gastrointestinal tract of broiler chickens by microorganisms might be affected by type of diet (Halliwell and Gutteridge, 2007). The anti-bacterial activity of propolis may be considered on two levels. First, it is connected with the direct action on the microorganism, and the other with stimulation of the immune system resulting in activation of natural defenses of the bird (Santos and González, 2017). This is in agreement with Bankova et al. (1995) who examined the activity of different fractions of Brazilian propolis towards Staphylococcus aureus, and observed that the antibacterial activity is mainly due to polar phenolic compounds. Melliou et al. (2007) reported that the volatiles of greek propolis inhibited four different species of Gram-negative bacteria (E. coli, E. cloacae, $K$. pneumoniae, $P$. aeruginosa). The ethanolic extract of Bulgarian propolis inhibited $90.9 \%$ of Gram-negative bacteria tested (Boyanova et al., 2006). Capasso, (2002) reported that propolis samples showed in vitro antimicrobial activity mainly against Gram-positive (Staphylococcus spp. and Streptococcus spp.) and Gram-negative bacteria (Escherichia coli, Klebsiella pneumoniae, Proteus vulgaris and Pseudomonas aeruginosa) (Bankova et al. 2007). 
Propolis has different antibacterial mechanisms, including inhibition of cell division, collapsing microbial cytoplasm cell membranes and cell walls, inhibition of bacterial motility, enzyme inactivation, bacteriolysis, and protein synthesis inhibition (Fernandes Júnior et al., 2005). propolis exerts a bactericidal effects against Gram-positive microorganisms and a bacteriostatic effect against Gram-negative microorganisms and this difference could be attributed to variable cell wall and membrane structure of the corresponding organisms (Issam et al., 2018). It has been reoprted that the propolis had antimicrobial properties against a wide range of Gram-positive bacterial pathogens and a usual effect against Gram-negative organisms as well as its signifcant antiviral action is due to its high contents of bio-flavonoids (Kamboh et al., 2017). Propolis fights diseases caused by Salmonella, Staphylococcus aureus, or Escherichia coli (Hascik et al., 2012). Propolis also had effect on normal gastrointestinal microflora which enhancing the beneficial bacteria and decreasing the pathogenic ones (Kačániová et al., 2012). Propolis, as a material composed to a large extent of plants secretions, is a rich source of cinnamic acid and esters. Many studies documented the antimicrobial activity of cinnamic acid against Vibrio spp., Ecoli, L.monocytogene, Mycobacterium tuberculosis, Bacillus spp., Staphylcoccus spp. Streptococcus pyogenes, Micrococcus flavus, $P$. aeruginosa, S.enterica serotype Typhimurium, Enterobacter cloacae and Yersinia ruckeri (Yilmaz et al., 2018). The way propolis exerts its antimicrobial action is complex and occur, among other things, through inhibition of the bacterial growth by inhibiting of its enzymatic activity diminishing their effects on biological systems (Zeighampour et al., 2014).

Sensory quality is crucial for consumer acceptance. Dietary supplementation is the key factor which can most easily be manipulated and has one of the most profound effects on sensory quality of meat (Joo et al., 2013). Sensory analysis either by people measure appearance, aroma, color, tast, texture, and sound or instruments measure physical or chemical characteristics of a product that can relate to the sensory experience (Lyon et al., 2010).

In the present study organoleptic evaluation of the breast muscle were improved by addition of propolis to chicken feed. Color is one of the most important quality attributes, and is related to the functional properties of the meat, directly impacting consumer product selection and cooked product appearance. (Jiang et al., 2017). Where propolis supplemented groups represent a significant effect on the breast muscle color when compared to E. coli infected and control groups, as demonstrated in other similar studies (Saláková et al., 2009; Sulcerová et al., 2011). The color of the meat is a feature that signifcantly determines its quality, as it is the first visual criterion for consumers to assess the appearance and attractiveness of meat. There by, the chicken breast muscle should be pink in color, and any deviation from this nuance is considered unacceptable to consumers (Garcia et al., 2010). Meat tenderness is defined by the ease of mastication, which involves initial penetration by the teeth, the breakdown of meat into fragments and the amount of residue remaining after chewing (Kong et al., 2008). The obtained results agreed with Haščík et al. 
(2015) who suggested that the dietary supplementation of propolis could improve meat tenderness of broilers. Anyway, propolis has been shown as the most favourable diet supplement in order to get good meat tenderness as well as getting the lowest roasting losses.

The positive effect of propolis in improving sensory quality of chicken breast muscle in supplemented groups were corresponded with the finding of Hašč́k et al. (2011) who noted positive results of sensory evaluation of the breast of the Ross 308 chickens with the application of propolis extract in amount of 200,300 and $400 \mathrm{mg} \cdot \mathrm{kg}-1$ in the feed mixtures.

In the current study, cardiac lesions were severe and diffuse in E. coli infected group. Similar results recorded by (Ghosh et al., 2006). While in E. colipropolis supplemented group, lesions were mild and focal, that may be attributed to propolis conistituents (CAPE, chrysin, acacetin) which has a cardioprotective role against the toxic doxorubicin by inhibiting the oxygen free radicals (Marcucci et al., 2000; Shalamany and Shivazad, 2006). Furthermore, propolis supplementation significantly reduces the concentration of triglycerides, cholesterol, nitric oxide, malonaldahyde, low density lipoproteins, and improves the levels of high density lipoprotein and superoxide dismutase activity which indicate that propolis could normalize the circulatory function (Huang et al., 2005; Nam et al.,2009).

Lung in E. coli infected group, showed degenerative changes in parenchyma, edema, haemorrhage and diffuse infiltration of inflammatory cells in the bronchus wall and parabronchial lumen, these results were supported by (Tonu et al., 2011). On the other side, lung was mostly normal in $E$. coli-propolis supplemented group, this may be due to caffeic acid phenethyl ester that showed a marked reduction in the infiltration of inflammatory cells within the peribronchiolar and perivascular regions (Hegazi and Abd El Hady, 2002).

Liver in E. coli infected group showed inflammatory and necrotic lesions, congested central vein and sinusoids with cellular infiltration around the portal area. These lesions may be due to E. coli endotoxin and vascular injury (Newairy and Abdou, 2013). The hepatic coagulative necrosis attributed to tissue hypoxia occasioned by vascular compromise (Abalaka et al., 2017). Liver in E. coli- propolis supplemented group showed mild hepatocytic vacuolar degeneration and mild focal congestion as propolis consist of (phenolics, diterpenes and bio-flavinoids) which consider as a strong hepatoprotective conistituents against $\mathrm{CCl} 4$ (carbon tetrachloride) which induces severe hepatocellular damage (Abd El Ghany and madian, 2011), and the long term intake of propolis could prevent the liver degeneration (El-Khatib et al., 2002).

The small intestine is an important and vital organ responsible for the diet digestion and absorption of nutrients, any histological changes affect its function will affect the function of other organs and systems (Mahmoud et al., 2014). In the current study, the recorded lesions of intestine in E. coli infected group were in the form of degeneration, necrosis and desquamation of mucosal epithelia associated with severe inflammation, these results agree with Islam et al. (2003). Propolis supplemented groups 
showed marked increasing of intestinal villi length and width with intact epithelium and hyperplasia of intestinal glands comparing to control and $E$ coli infected groups, which leading to increase the intestinal surface area and improve the nutrients absorption and improve the weight gain as explained by Ahn et al. (2007).

Histopathological examination of E. colipropolis supplemented group in all examined organs were mostly normal, these results explained by De Moura et al. (2011) and Woo et al. (2005) who reported that some propolis constituents (Quercetin, caffeic acid phenethyl ester (CAPE) and chrysin) have a mediating role against the chronic inflammation, by inhibiting gene expression of $\mathrm{TNF} \alpha$ and reduces the synthesis of prostaglandis and leukotrienes. Moreover, propolis has the ability to inhibit the activation of NLRP3 inflamatory factors through decreasing the reactive oxygen species production and impair the expression of interleukin-1beta (Pushpavalli et al., 2010; Izuta et al., 2009).

In the current study, E. coli infected group showed a significant decrease in the immune reactive positive cells in spleen and bursa (CD79A), and in thymus (CD79A), these results supported by Abd El-Tawab et al. (2015) who recorded a significant decrease in phagocytic activity, phagocytic index and weight of bursa of Fabricius, thymus and spleen in $E$. coli infected broilers. Propolis supplemented groups showed enhancement of lymphocytic proliferation in lymphoid organ compared to control group, that agree with Hegazi and Abd El Hady (2002) who reported that propolis supplementation reflect in the lymphoid organs development and weight, impacting on immune function and disease resistance ability.

\section{CONCLUSION}

Escherichia coli infection is a major worldwide proplem due to increasing antibiotic resistance and increasing the hazard of spreading antibiotic resistance genes. Propolis efficiently decreased the adverse effect of $E$. coli infection, it decreased morbidity and mortality, increased significantly body weight and resulted in early recovery of $E$. coli infection. Also, it enhanced the phagocytic activity and ND antibody production. Moreover, the diversity of chemical bioactive compounds of propolis are responsible for the growth promotor, immune-modulatory, antibacterial, antiviral, antifungal activity. Furthermore it gives propolis an additional advantage as antibacterial agent, the combination of different active ingredients with different concentrations prevents the bacterial resistance from occurring. It also improves the poultry meat quality. So the use of propolis as a natural supplement in poultry feed would be promising in poultry industry.

\section{REFERENCES}

Abalaka, S.E.; Sani, N.A.; Idoko, I.S.; Tenuche, O.Z.; Oyelowo, F.O.; Ejeh, S.A. and Enem, S.I. (2017): Pathological changes associated with an outbreak of colibacillosis in a commercial broiler flock. Sokoto Journal of Veterinary Sciences, 15(3): 95

Abd El Ghany, A. and madian, F.K. (2011): Egyptian propolis: 2.Chemical composition, antiviral and antimicrobial activities of East 
Nile Delta propolis. Zeitschrift fur Naturforschung C. 57 (3-4): 386394.

Abd El Hady, F.K. and Hegazi, A.G. (2002): Egyptian propolis: 2: Chemical composition, antiviral and antimicrobial activities of East Nile Delta propolis. Z Naturforschc J Biosci. 57(3-4): 386-94.

Abd El-Rahman, M.A. and Mosaad, G.M. (2013): Effect of propolis as additive on some behavioral patterns, performance and blood parameters in Muscovy broiler ducks. Journal of Advanced Veterinary Research 3: 64-68.

Abd El-Tawab, A.A.; Komy, A.A.; Khalid, E.E.; Ekhnawy, I. and Talaie, A.T. (2015): Effect of fosfomycin on $E$. coli $\mathrm{O} 78$ isolated from broiler chicken in-vitro and in-vivo. Benha Veteterinary Medical Journal. 28(1): 294-300.

Ahn, M.R.; Kumazawa, S.; Usui, Y.; Nakamura, J. and Matsuka, M. (2007): Antioxidant activity and constituents of propolis collected in various areas of China. Food Chem; 101: 1383-92.

Anis, Z.; Azuma, K.; Ito, H. and Shimada, A. (2013): Comparative study on the pathogenesis of the generated 9a5b Newcastle disease virus mutant isolate between chickens and waterfowl. Veterinary pathology, 50(4): 638-647.

Anthony, T.W.C.; Twin, K.M.L.; Erin, M.W. and Michael, E.M. (1985): Phagocytic and killing capacities of uterine derived leukocytes from mares resistant and susceptible to chronic endometritis. Am. J. Vet. Res., 46(9): 1938-1940.

AOAC. (1990): Official methods of analysis. 15th revised ed. Washington, DC, USA: Association of Official Analytical Chemists; 1990.ISSN 1364-507

Attia Y.A.; Al-Khalaifah, H.; Ibrahim, M.S.; Abd Al-Hamid, A.E.; AlHarthi, M.A. and El-Naggar, A. (2017): Blood Hematological and Biochemical Constituents, Antioxidant Enzymes, Immunity and Lymphoid Organs of Broiler Chicks Supplemented with Propolis, Bee Pollen and Mannan Oligosaccharides Continuously or Intermittently. Poultry Science 96:4182-4192.

Attia, Y.A.; AbdAl-Hamid, A.E.; Ibrahim, M.S.; Al-Harthi, M.A.; Bovera, F. and Elnaggar, A.S. (2014): Productive performance, biochemical and hematological traits of broiler chickens supplemented with propolis, bee pollen, and mannan oligosaccharides continuously or intermittently. Livestock Science 164: 87-95.

Awad, N.F.S.; Abd El-Hamid, M.I.; Hashem, Y.M.; Erfan, A.M.; Abdelrahman, B.A. and Mahmoud, H.I. (2019): Impact of single and mixed infections with Escherichia coli and Mycoplasma gallisepticum on Newcastle disease virus vaccine performance in broiler chickens: an in vivo perspective. Journal of Applied Microbiology ISSN 13645072.

Babaei, S.; Rahimi, S.; Karimi, M.A.; Tahmasebi, G. and Khaleghi, S.N. (2016): Effects of propolis, royal jelly, honey and bee pollen on growth performance and immune system of Japanese quails. Veterinary Research Forum, 7(1), 13-20

Babinska, I.; Kleczek, K.; Makowski, W. and Szarek, J. (2013): Effect of 
feed supplementation with propolis on liver and kidney morphology in broiler chickens. Pakistan Veterinary Journal 33: 1-4.

Bancroft, J.D.; Layton, C. and Suvarna, $K$. (2013): Bancroft's Theory and Practise of Histological Techniques (7th edition), Publisher: Elsevier ISBN: 978-0-7020-4226-3.

Bankova, V.; Christov, R.; Kujumgiev, A.; Marcucci, M.C. and Popov, S. (1995): chemical composition and antibacterial activity of Brazilian propolis. Z. Naturforsch 50, 167172.

Bankova, V.; Popova, M. and Trusheva, $B$. (2007): Plant origin of propolis: Latest developments and importance for research and medical use. In: Apicultura - De la stiinta la agribusiness si apiterapie. L.A. Margitas, Dezmirean, D., Editura Academic Pres, Cluj Napoca, pp. 40-46.

Biswas, S.; Das, A.K.; Banerjee R. and Sharma, N. (2007): Effect of electrical stimulation on quality of tenderstretched chevon sides. Meat Sci. 75, 332-336. Meatsci. 2006.08.002 PMID: 22063666.

Boyanova, L.; Kolarov, R.; Gergova, G. and Mitova, I. (2006): In vitroactivity of Bulgarian propolis against 94 clinical isolates of anaerobic bacteria. Anaerobe, 12,173-177.

Boyum, A. (1968): Isolation of mononuclear cells and granulocytes from human blood. Canadian J. Clin. 21: 77-89.

Brugh, M.J. (1978): A simple method for recording and analyzing serological data. Avian Dis. 22(2): 362-365.

Bryan, L.E. (1982): Bacterial resistance and suspectibility to chemotherapentic agents. Sydney: McGraw-Hill Co. p 20-24.
Capasso, F. and Castaldo, S. (2002): Propolis, an old remedy used in modern medicine. Fitoterapia. 73: 1-6.

Cetin, E.; Silici, S.; Cetin, N. and Guclu, B.K. (2010): Effects of Diets Containing Different Concentrations of Propolis on Hematological and Immunological Variables in Laying Hens. Poultry Science 89: 1703-1708

Chu, Y. and Dietert, R.R. (1989): Monocytes function in chicken with hereditary dystrophy. Poult. Sci., 68: 226-232.

Corzo, A.; Schilling, M.W.; Loar, R.E.; Jackson, V.; Kin, S. and Radhakrishnan, V. (2009): The effects of feeding distillers dried grains with solubles on broiler meat quality. Poult Sci, 88, 432-439. https://doi.org/10.3382/ ps.200800406 PMID: 19151359.

De Moura, S.A.; Negri, G.; Salatino, A.; Cunha, L.D.; Antunes Dourado, L.B. and Mendes, J.P. (2011): Aqueous Extract of Brazilian Green Propolis: Primary Components, Evaluation of Inflammation and Wound Healing Pharmacol. 600 (3): 122-133.

Drago, L.; Mombelli, B.; Vecchi, E.D.; Fassina, M.C.; Tocalli, L. and Gismondo, M.R. (2000): In vitro antimicrobial activity of propolis dry extract. J Chemother 12:390395.

Drażbo, A.K.; Kozłowski, K.; Ognik, A.; Zaworska, J. and Jankowski, $N$. (2019): The effect of raw and fermented rapeseed cake on growth performance, carcass attributes, and breast meat quality in Turkey Poult. Sci., 98 pp. 6161-6169, 10.3382/ ps/pez322.

El-Khatib, A.S.; Agha, A.M.; Mahran, L.G. and Khayyal, M.T. (2002): 
Prophylactic effect of aqueous propolis extract against acute experimental hepatotoxicity in vivo. Z Naturforsch C. 57 (3-4): 379-385.

El-Saadany, H.A. (2017): Case series: Association between elevated circulating plasmablasts and their gated flow-cytometric picture in a cohort of IgG4-RDcases. J Clin Cell Immunol.

Eyng, C.; Murakami, A.E.; Santos, T.C.; Silveira, T.G.V.; Pedroso, R.B. and Lourenço, D.A.L. (2015): Immune Responses in Broiler Chicks Fed Propolis Extraction Residuesupplemented Diets. Asian Australas. J. Anim. Sci. 28:135142 .

Eyng, C.; Murakami, A.E.; Pedroso, R.B.; Silveira, T.G.V.; Lourenco, D.A.L. and Garcia, A.F.Q.M. (2013): Crude propolis as an immunostimulating agent in broiler feed during the starter phase. Semina: Ciências Agrárias, Londrina, v. 34, n. 5, p. 2511-2522.

Fan, Y.; Lu, Y.; Wang, D.; Liu, J.; Song, $X . ;$ Zhang, W.; Zhao, X.; Nguyen, T.L and Hu, H. (2013): effect of epimedium polysaccharide-propolis flavone immunopotentiator on immune suppression induced by cyclophosphamide in chickens. Immunol. 281(1): 37-43.

Fernandes Júnior, A.; Balestrin, E.C.; Betoni, J.E.C.; Orsi, R.D.O.; Cunha, M.D. and Montelli, A.C. (2005): Anti-Staphylococcus aureus activity and synergism with antimicrobial drugs. Mem.Inst. Oswaldo Cruz. 100:563-566.

Food and Drug Administration "FDA" (2012): Bad bug book:Foodborne pathogenic microorganisms and natural toxins handbook, 2nd ed. US Food and Drug Administration, Silver Spring, p. 87-92.
Freitas, J.A.; Vanat, N.; Pinheiro, J.W.; Balarin, M.R.S.; Sforcin, J.M. and Venancio, E.J. (2011): The Effects of Propolis on Antibody Production by Laying Hens. Poultry Science 90: 1227-1233.

Galal, A.; Abd El-Motaai, A.M.; Ahmed, A.M.H. and Zaki, T.G. (2008): Productive performance and immune response of laying hens as affected by dietary propolis Supplementation. International Journal of Poultry Science 7: 272278.

Garcia, R.G.; Freitas, I.W.; Schwingel, A.W.; Farias, R.M.; Caldara, F.R.; Gabriel, A.M.A.; Graciano, J.D.; Komiyama, C.M. and Almeida, I.C.I. (2010): Incidence and physical properties of PSE chicken meat in a commercial processing plant. Braz. J. Poultry Sci. 12, 233237.

Ghosh, R.C.; Hirpurkar, S.D. and suryawnshi, P.R. (2006): Concurrent Colibacillosis and infectious bursal disease in broiler chicks. Indian Veterinary Journal 83: 1019-1020.

Giurgea, R.; Toma, V.; POpescu, H. and Linicencu, C. (1981): Effect of standaraized propolis extract on certain blood conistituents in chickens. Clujul-Medical, 54: 151154.

Goddeeris, B.M.; Baldwin, C.L.; OleMoiyoi, O. and Morrison, I. (1986): Improved methods for purification and depletion of monocytes from bovine peripheral blood mononuclear cells. Functional evaluation of monocytes in responses to lectins. Journal of Immunological Methods, 89(2): 165-173.

Gregačević, L.; Klarić, I.; Domaćinović, M.; Galović, D. and Ronta, M. 
(2014): Phytogenic additives in domestic animals nutrition. Krmiva 56, 117-123.

Gunya, B.; Muchenje, $\quad$. and Masika, P.J. (2019): The effect of earthworm Eisenia foetida meal as a protein source on carcass characteristics and physico to chemical attributes of broilers. Pak. J. Nutr. 18, pp. 657-664.

Halliwell, B. and Gutteridge, J.M.C. (2007): Free radicals in biology and medicine. Oxford University Press, United Kingdom, 2007, pp. 851.

Hams, M.A.M. and Waleed, Y. (2018): Trials on the Role of Prebiotics and Probiotics in Colonization and Immune Response of Broiler Chickens Challenged with Escherichia Coli K88. AJVS. Vol. 58 (1): 48-56.

Hasan, B.R.; Faruque, M.; Drobni, J.; Waldenstrom, A.; Sadique, K.U. and Ahmed, Z. (2011): High prevalence of antibiotic resistance in pathogenic Escherichia coli from large and small-scale poultry farms in Bangladesh. Avian Diseases. 55:689-692.

Haščík, P.; Trembecká, L.; Bobko, M.; Kačániová, M.; Čuboň, J.; Kunová, S. and Bučko, O. (2016): Effect of diet supplemented with propolis extract and probiotic additives on performance, carcass characteristics and meat composition of broiler chickens. Potravinarstvo, vol. 10 no. 1, p. 223-231 doi:10.5219/581.

Haščik, P.; Garlík, J.; Elimam, I.O.E.; Kačániová, M.; Pochop, I.; Bobko, M.; Kročko, M. and Benczová, E. (2011): Sensory quality of poultry meat after propolis application. Journal of Microbiology, Biotechnology and Food Sciences 1: 172-186.
Haščik, P.; Garlík, J.; Kňazovická, M.; Mkačániová, V.; Omer, I.; Elimam, E.; Pochop, J.; Benczová, E. and Vavrišinová $\quad K . \quad$ (2012): Technological properties of chickens' meat after application of propolis extract in their diet. J. Microbiol. Biotechnol. Food Sci. 1, 1295-1304.

Haščik, P.; Trembecká, L.; Bobko, M.; Čuboň, J.; Bučko, O. and Tkáčová, J. (2015): Evaluationof meat quality after application of different feed additives in dite of broiler chicken. 9, no. 1, p. 174-182.ISSN 1337-0960 (online).

Hassan, M.G. and Abdulla, T.A. (2011): The effect of propolis feed supplementation on hygiene and performance of broiler chickens. Iraqi Journal of Veterinary Science 25: 77-82.

Hassan, R.I.M.; Mosaad, G.M.M. and Abd El-wahab, H.Y. (2018): Effect of Feeding Propolis on Growth Performance of Broilers. Journal of Advanced Veterinary Research Volume 8, Issue 3. 66-72

Hassanin, O.; Abdallah, F. and Awad, A. (2014): Effects of florfenicol on the immune responses and the interferon inducible genes in broiler chickens under the impact of $E$. coli infection. Vet. Res Commun 38, 51-58.

Hegazi, A.G. and Abd El Hady, F.K. (2002): Egyptian propolis: Antioxidant, antimicrobial activities and chemical composition of propolis from reclaimed lands. Z Naturforsch, vol. 200; 57: 395-402.

Hegazi, A.G.; Abdou, A.M. and Abd Allah, F.M. (2014): Egyptian propolis 11: Its antimicrobial activity with comparison with different localities. Int. J. Curr. Microbio. App.Sci. 3(9)530-538. 
Hegazy, A.M.; Abd-El Samie, L.K. and ELSayed, E.M. (2010): The immunosuppressive effect of $E$. coli in chickens vaccinated with infectious bronchitis (IB) or infectious bursal disease (IBD) vaccines. J Am Sci 6, 762-767.

Huang, S.S.; Liu, S.M.; Lin, S.M.; Liao, P.H.; Lin, R.H.; Chen, Y.C.; Chih, C.L. and Tsai, S.K. (2005): Antiarrhythmic effect of caffeic acid phenethyl ester (CAPE) on myocardial ischemia/reperfusion. injury in rats. Clin. Biochem. 38 (10): 943-947.

Hussain, A.; Shaik, S.; Ranjan, A.; Nandanwar, N.; Tiwari, S.K.; Majid, M.; Baddam, R.; Qureshi, I.A.; Semmler, T.; Wieler, L.H.; Islam, M.A.; Chakravortty, D. and Ahmed, N. (2017): Risk of transmission of antimicrobial resistant Escherichia coli from commercial broiler and free- range retail chicken in india. Frontiers in microbiology. Volume 8, article 2120

International Organization for Standardization Microbiology of Food and Animal Feeding Stuffs (ISO, 2001): Horizontal method for the detection and enumeration of Enterobacteriaceae- Colony count technique. Geneva.

Islam, M.R.; Das, B.C.; Hossain, K.H.; Lucky, N.S. and Mostafa, M.G. (2003): A study on the occurrence of poultry disease in Sylhet Region of Bangladesh. International Journal of Poultry Science 2: 354356.

Issam, A.A.; Stefan, Z.; Jürgen, $R$. and Michael, W. (2018): Antimicrobial Activities of European Propolis Collected from Various Geographic.
Izuta, H.; Narahara, Y.; Shimazawa, M.; Mishima, S.; Kondo, S. and Hara, $H$. (2009): 1,1-Diphenyl-2picrylhydrazyl Radical Scavenging Activity of Bee Products and Their Constituents Determined by ESR. Biol. Pharma. Bulletin. 32 (12): 1947-1951.

Janković, L.J.; Petrujkić, B.; Aleksić, N.; Vučinić, $\quad$ M.; Teodorović, N.; Karabasil, $\quad$ N.; Relić, R.; Drašković, $V$. and Nenadović, $K$. (2020): Carcass characteristics and meat quality of broilers fed on earthworm (Lumbricus rubellus) mealJ. Hell. Vet. Med. Soc., 71 (2020), pp. 2031-2040.

Jiang, H.; Yoon, S.C.; Zhuang, H. and Wang, W. (2017): Predicting color traits of intact broiler breast fillets using visible and near-infrared spectroscopy. Food Anal Methods. 10:3443-51. doi: 10.1007/s12161017-0907-1

Joo, S.; Kim, G.; Hwang, Y. and Ryu, Y. (2013): Control of fresh meat quality through manipulation of muscle fiber characteristics. Meat Science, 95(4), 828-836.

Kacaniova, M.; Rovna, K.; Arpasova, H.; Cubon, J.; Hleba, L.; Pochop, J.; Kunova, S. and Hascik, P. (2012): In vitro and in vivo antimicrobial activity of propolis on the microbiota from gastrointestinal tract of chickens. Journal of Environmental Science and Health Part A Toxic /Hazardous Substances \& Environmental Engineering, 47(11), 1665-1671.

Kamboh, A.; Memon, A.; Mughal, M.; Memon, J. and Bakhetgul, $M$. (2017): Dietary effects of soy and citrus flavonoid onantioxidation and microbial quality of meat in broilers. J. Anim. Physiol. Anim. Nutr3 (1): 6-30. 
Khaksefidi, A. and Rahimi, S.H. (2005): Effect of Probiotic Inclusion in the Diet of Broiler Chickens on Performance, Feed Efficiency and Carcass Quality, AsianAustralasian Journal of Animal Sciences, 2005, 8, 1153-1156.

Klaric, I.; Matija, D.; Vatroslav, S.; Ivan, M.; Mirela, P. and Ksenija. (2018): Effects of bee pollen and propolis on performance, mortality, and some haematological blood parameters in broiler chickens. Slov Vet Res 2018: 55 (1): 23 -34

Kong, F.; Tang, J.; Lin, M. and Rasco, B. (2008): Thermal effects on chicken and salmon muscles: Tenderness, cook loss, area shrinkage, collagen solubility and microstructure. LWT-Food Science and Technology, vol. 41, no. 7, p. 12101222.

Krell, R. (1996): Value-added products from bee keeping. Milan, FAO agricultural services no. 124, Publications, 395 p. ISBN 92-5103819-8.

Kumari, M.; Rajendar, P.G.; Deepika, L. and Preeti, B. (2020): Ameliorating effect of Withania somnifera root extract in Escherichia coli-infected broilers. Poultry science. 99(4): 1875-1887.

Kurek-Górecka, A.; Rzepecka-Stojko, A.; Górecki, M.; Stojko, J.; Sosada, M. and Swierczek-Zieba, G. (2014): Structure and antioxidant activity of polyphenols derived from propolis. Molecules, 19(1), 78-101. DOI: 10.3390/molecules 19010078

Lucky, Z. (1977): Methods for diagnosis of fish disease. New Delhi, Bomby, New York.: Ameruno publishing Co.

Lyon, B.G.; Lyon, C.E.; Meullenet, J.F. and Lee, Y.S. (2010): Meat quality: Sensory andinstrumental evaluations. Pages 125-155 in Poultry Meat Processing.2nd ed. Owens, C.M., C.Z. Alvarado, and A.R. Sams, ed. CRC Press, Boca Raton, FL.

Mahmoud, U.T.; AbdEl-Rahman, M.A. and Darwish, M.H.A. (2014): Effects of propolis, ascorbic acid and vitamin $\mathrm{e}$ on thyroid and corticosterone hormones in heat stressed broilers. Journal of Advanced. Veterinary Research 1: 18-27.

Mahmoud, U.T.; AbdEl-Rahman, M.A. and Darwish, M.H.A. (2013): The effect of Chinese propolis supplementation on Ross broiler performance and carcass characteristics. Journal of Advanced Veterinary Research 3: 154-160

Marcucci, M.C.; Ferreres, F.; Custodio, A.R.; Ferreira, M.M.; Bankova, V.S.; Garcia-Viguera, C. and Bretz, W.A. (2000): Evalution of phenolic compounds in Brazilian propolis from different geographic regions. Zeitschrift Fur Naturforschung C-a J.Biosci. 55 (1-2): 76-81.

Melliou, E.; Stratis, E. and Chinou, I. (2007): Volatile constituents of propolis from various regions of greece - Antimicrobial activity. Food Chem. 103, 375-380.

Mirzoeva, O.K.; Grishanin, R.N. and Colder, P.C. (1997): Antimicrobial action of propolis and some of its components: the effect on growth, membrane potential and motility of bacteria. Microbiol Res 152:239246.

Mohamed, N.E.; Sharawi, S.; Omar, R.E.; El-Habbaa, A.S. and SaadAllah, E.T. (2019): Immunomodulation of broiler chicks to live NDV vaccine by natural supplements. Benha 
Veterinary Medical Journal, Vol. 36, No. 2:90-99, June.

Nakamura, K.; Yuasa, N.; Abe, H. and Narita, M. (1990): Effect of Infectious bursal disease virus on infections produced by Escherichia coli of high and low virulence in chickens. Avian patho.19: 713721.

Nam, J.H.; Shin, D.H.; Zheng, H.; Kang, J.S.; Kim, W.K. and Kim, S.J. (2009): Inhibition of store-operated $\mathrm{Ca} 2+$ entry channels and $\mathrm{K}+$ channels by caffeic acid phenethylester in $\mathrm{T}$ lymphocytes. European J. Pharmacol. 612 (1): 153-160.

Newairy, A.A. and Abdou, H.M. (2013): Effect of propolis consumption on hepatotoxicity and brain damage in male rats exposed to chlorpyrifos. African Journal of Biotechnology 12: 5232-5243.

Odetunde, S.K.; Lawal, A.K.; Akolade, M.A. and Bakry, S.B. (2011): Microbial flora of frozen chicken part varieties. International Research Journal.

Omar, R.E.M.; Mahmoud, E.A.; Karousa, M.M. and Randa, S.A. (2002): Effects of additives propolis and Nigella sativa seed oil on some behavioural patterns, performance products and blood parameters in Sasso chickens. Egypt Poult. Sci. 21: 140-51

Orsi, R.O.; Funari, S.R.C.; Soares, A.M.V.C.; Calvi, S.A.; Oliveira, S.L.; Sforcin, J.M. and Bankova, V. (2000): Immunomodulatory action of propolis on macrophage activation. Journal of Venomous Animals and Toxins including Tropical Diseases, Botucatu 6: 205219.
Pamplona, B.C.; $\quad$ Da Silva, C.B.; Marcucci, M.C. and Mimica. L.M. (2011): Evaluation of the invitro antimicrobial activity of ethanolic extract of brazillian classified propolis on strains of Staphylococcus aureus. Braz. J. Microbiol. 42, 1259-1264.

Patil, V.B. (2018): Effect of Azadirachta indica leaf powder in prevention of Colibacillosis in broilers. M.V.Sc. thesis submitted to College of Veterinary and Animal Sciences, Udgir, MAFSU, Nagpur, 2018.

Pelin-Can, O. and Arslan, A. (2011): Determination of shelf life of marinated carp fillets. Biotechnology in Animal Husbandry27 (1), 101-11.

Pushpavalli, G.; Kalaiarasi, $\quad P$. ; Veeramani, C. and Pugalendi, K.V. (2010): Effect of chrysin on hepatoprotective and antioxidant status in D-galactosamine-induced hepatitis in rats. Eur. J. Pharmacol. 631 (1-3): 36-41.

Rabie, A.H.; El-Kaiaty, A.M.; Hassan, M.S.H. and Stino, F.K.R. (2018): influence of some honey bee products on some haematological and immunological parameters and meat quality in broilers. Egypt. Poult. Sci. Vol (38) (II): (533-549)

Ramadan, H.; Jackson, C.R.; Frye, J.G.; Hiott, L.M.; Samir, M.; Awad, A. and Woodley, T.A. (2020): Antimicrobial Resistance, Genetic Diversity and Multilocus Sequence Typing of Escherichia coli from Humans, Retail Chicken and Ground Beef in Egypt. Pathogens, 9,357

Saláková, A.; Straková, E.; Válková, V.; Buchtová, H. and Steinhauserová, I. (2009): Quality indicators of chicken broiler raw and cooked 
meat depending on their sex. Acta Vet. Brno 78, 497-504.

Santos, F.A.; Bastos, E.M.A.; Uzeda, M.; Carvalho, M.A.R.; Farias, L.M.; Moreira, E.S.A. and Braga, F.C. (2002): Antibacterial activity of Brazilian propolis and fractions against oral anaerobic bacteria. J Ethnopharmacol 80:17.

Santos-Buelga, $\quad$ C. and GonzálezParamás, A.M. (2017): Bee

Products-Chemical and Biological Properties. Springer;

Gewerbestrasse, Switzerland: Phenolic composition c of propolis; pp. 99-111.

Schalm, O.W. (1986): Veterinary hematology. 4th Ed. Philadelphia, USA: Lea and Febigez.

Seven, I.; Aksu, T. and Tatli, S.P. (2012): The effects of propolis and vitamin c supplemented feed on performance, nutrient utilization and carcass characteristics in broilers exposed to lead. Livestock Science 148: 10-15.

Seven, I.; Tatli, S.P. and Silici, S. (2011): Effects of dietary Turkish propolis as alternative to antibiotic on growth and laying performances, nutrient digestibility and egg quality in laying hens under heat stress. Revue de Médecine Vétérinaire 162: 186-191.

Sforcin, J.M. (2007): Propolis and the immune system: A review. Journal of Ethnopharmacology 113: 1-14.

Shalmany, K.S. and Shivazad M. (2006): The effect of diet propolis supplementation on Ross broiler chicks' performance. Int. J. Poult. Sci.; 5: 84-8.

Shihab, I.M. and Ali, B.H. (2012): Effect of propolis in diet supplementation on the immune response against Newcastle disease and hematological picture in broiler chicks. Al-Anbar Journal of Veterinary Sciences 5: 40-46.

Steel, R.G.D and Torrie, J.H. (1980): principles and procedures of Statistics. $2^{\text {nd }}$ ed. McGraw HillBook Company, New York.

Sulcerová, H.; Mihok, M.; Jůzl, M. and Haščik, P. (2011): Effect of addition of pollen and propolis to feeding mixtures during the production of broiler chickens Ross 308 to the colour of thigh and breast muscle and $\mathrm{pH}$ determination. Acta Univ. Agric. et Silvic. Mendel. Brun. 59, 359-366.

Taheri, H.R.; Rahmani, H.R. and Pourreza, J. (2005): Humoral immunity of broilers is affected by oil extracted propolis (OEP) in the diet. International Journal of Poultry Science 4: 414-417.

Takatsy, G. (1955): The Use of Spiral Loops in Serological and Virological Micro-Methods. Acta Microbiol. Acad. Sci. Hung. 3: 191202.

Talas, Z.S. and Gulhan, M.F. (2009): Effects of various propolis concentrations on biochemical and hematological parameters of rainbow trout (Oncorhynchus mykiss). Ecotoxicol Environ Saf. 72: 1994-8.

Tandale, R.U.; Moregaonkar, S.D.; Gangane, G.R.; Dhumal, M.V.; Deshpande, A.R.; Ghorpade, P.B. and Chavan, P.A. (2019): Hematobiochemical assessment of induced E. coli infection in broiler birds and treated with Curry leaves powder (Murraya koenigii) and Leofloxacin. Journal of Entomology and Zoology Studies. 7(6): 1020-1025

Tatli, S.P. and Seven, I. (2008): Effect of Dietary Turkish Propolis as Alternative to Antibiotic on 
Performance and Digestibility in Broilers Exposed to Heat Stress. Journal of Applied Animal Research 34: 193-196.

Tekeli, A.; Kutlu, H.R. and Celik, L. (2011): Determination of the effect of Z. officinale and propolis extracts on intestinal microbiology and histological characteristics in broilers. Int. J. Poult. Sci. 9(9): 898906.

Tekeli, A.; Kutlu, H.R.; Celik, L. and Doran, F. (2010): Effect of Z. officinale and propolis extracts on the performance, carcass and some blood parameters of broiler chicks. Current Research in Poultry Science 1: 12-23.

Tonu, N.S.; Sufian, M.A.S.; Sarker, M.M.; Kamal, M.H. and Rahman, M.H. (2011): Pathological study on colibacillosis in chickens and detection of E. coli by PCR. vol. 11, 2: 111-1123.

Toomer, O.T.; Livingston, M.L.; Wall, B.; Sanders, $\quad E . ; \quad V u, \quad T . C$. ; Malheiros, R.D.; Livingston, K.V.; Carvalho, L.V. and Ferket, P.R. (2019): Meat quality and sensory attributes of meat produced from broiler chickens fed a high oleic peanut dietPoult. Sci., 98, pp. 51885197.

Umar, A.; Kamil, S.A.; Wani, B.M.; Qureshi, S.; Shah, S.A.; Tanveer, A.D.; Adil, S. and Mir, M.S. (2020): Haematological and Biochemical Alterations of Broiler Chicken Affected Naturally with Colibacillosis. Int. J. Curr. Microbiol. App. Sci. 9(6): 19061913.

United States Department of Agriculture (USDA) (2011): Quantitative Analysis of Bacteria in Foods as Sanitary Indicators January 2011
Wang, B.J.; Lien, Y.H. and Yu, Z.R. (2004): $\quad$ Supercritical fluid extractive fractionation-study of the antioxidant activities of propolis. Food Chemistry 86:237243.

Weibel, E.R. (1969): Stereological Principles for Morphometry in Electron Microscopic Cytology1. In International review of cytology, Vol. 26, pp. 235-302.

Wilkinson, P.C. (1976): Recognization and response in mononuclear and granular phagocytes. Clin. Exp. Immunol., 25(3):355-366.

Wilson, C.O. and Gisvold, O. (1982): Text book of Organic medicinal and pharmaceutical chemistry. 8th Ed. Fatah AM (ed). Jakarta: Dirjen Dikti dan Kebudayaan 10-12.

Woo, K.J.; Jeong Y.J.; Inoue, H.; Park, J.W. and Kwon, T.K. (2005): Chrysin suppresses ipopolysaccharide-induced cyclooxygenase-Academic

Publishers Journal of Animal Health and Production August, 579 (3): 705-711.

Yang, T.; Wange, D.; Xuanliang, H.U.; Huang, $Y$.; $Y u, Y$. and Wang, $D$. (2014): The immunological enhancement activity of propolis flavonoids liposome in vitro and invivo. Evid Based Complement Alternat Med. 2014:483513. doi: 10.1155/2014/483513.

Yilmaz, L.; Yilsay, T.O. and Bayazit, A.A. (2003): Chemical composition of propolis, properties and biological effects on human health. II. Marmara Apiculture Congress, pp. 28-30.

Yilmaz, S.; Sova M. and Ergün S. (2018): Antimicrobial activity of transcinnamic acid and commonly used antibiotics against important fish pathogens and nonpathogenic 
isolates. J. Appl. Microbiol. 125: 1714-1727.

Zabaiou, N.; Fouache, A.; Trousson, A.; Baron, S.; Zellagui, A.; Lahouel, $M$. and Lobaccaro, J.A. (2017): Biological properties of propolis extracts: Something new from an ancient product. Chem. Phys. Lipids. 207: 214-222.

Zduńczyk, Z. and Jankowski, J. (2013): Poultry meat as functional food: modifcation of the fatty acid profle - a review. Ann. Anim. Sci. 13, 463-480. DOI: 10.2478/ aoas2013-0039
Zeighampour, F.; Mohammadi-Sichani, M.; Shams, E. and Naghavi, N.S. (2014): Antibacterial activity of propolis ethanol extract against antibiotic resistance bacteria isolated from burn wound infections. Zahedan J. Res. Med. Sci. 16(3): 25-30.

Ziaran, H.R.; Rahmani, H.R. and Pourreza, J. (2005): Effect of dietary oil extract of propolis on immune response and broiler performance. Pakistan Journal of Biological Science 8: 1485-1490. 


\section{تأثير البروبوليس على الاستجابة المناعية و جودة اللحم فى بدارى التسمين المعداه اصطناعيا} بالميكروب القولونى جودة

منس سعيل /براهيم سليم ، نجلاء عباس الطيب عبل الحمبل ، هالة محمد اسعاعيل حبيب

E-mail: dr_mona.saidibrahim@yahoo.com Assiut University web-site: www.aun.edu.eg

تم اجراء هذه الدراسة لتقييم تأثثير البروبوليس على معدل النمو والاستجابة المناعي وجودة اللحم فى إنى

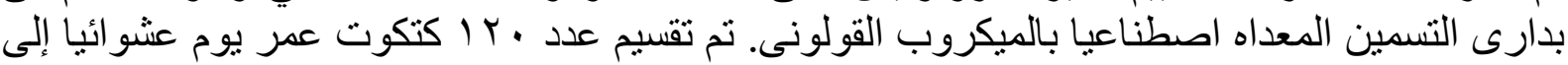

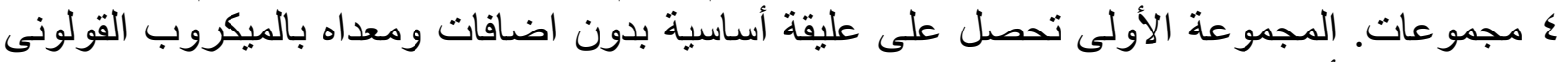

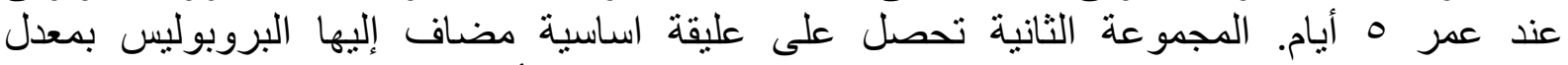

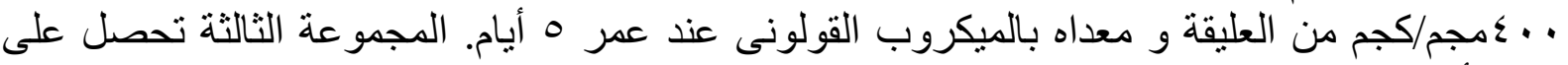

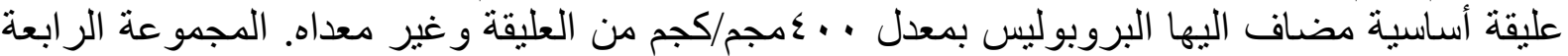

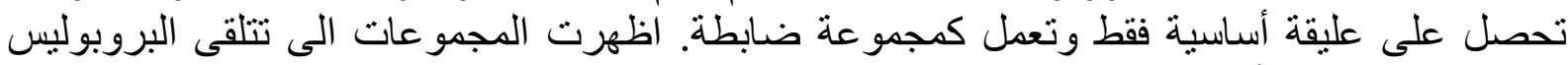

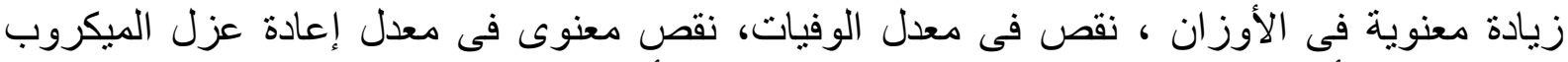

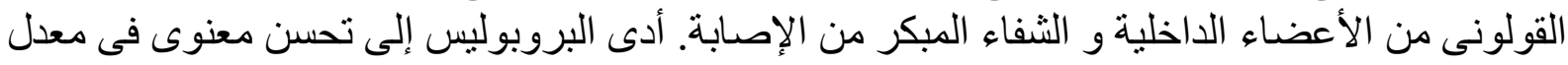

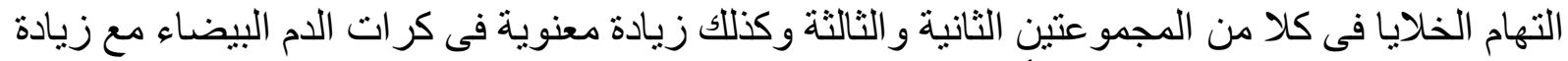
الليمفوسايت ونقص فى الهتيروفيل. أدى البروبوليس إلى تحسن فى رد الفعل المناعى لتحصين النيوكاسيل

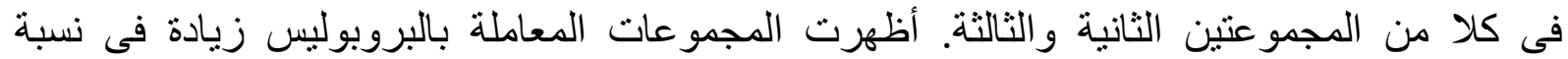
البروتين ونقص نسبة الدهون فى صدور الدجاج وكذللك نقص معنوى فى الحمل البكتيرى عند مقارنتها بالمجمو عة الأولى و الر ابعة. 